\title{
Effects of Ligand Substitution on the Optical and Electrochemical Properties of (Pyridinedipyrrolide)zirconium Photosensitizers
}

Yu Zhang, Dylan C. Leary, Anne M. Belldina, Jeffrey L. Petersen, Carsten Milsmann*

C. Eugene Bennett Department of Chemistry, West Virginia University, 100 Prospect Street Morgantown, WV, USA, 26506.

camilsmann@mail.wvu.edu

Supporting Information 


\section{Contents}

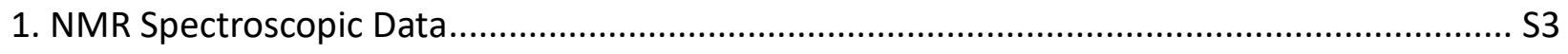

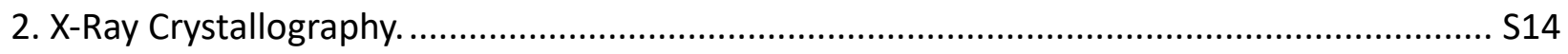

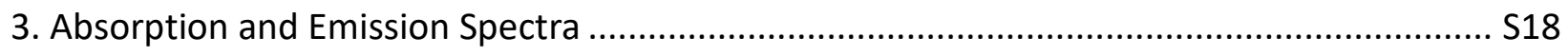

4. Quantum Yield Determination ............................................................................... S22

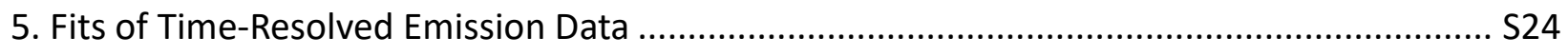

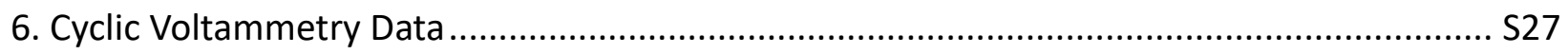

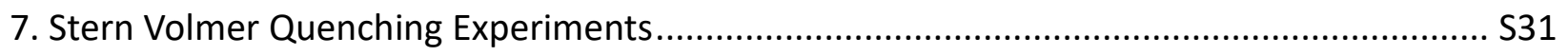

8. General procedure for photocatalytic dehalogenation of aryl halides.............................. S33

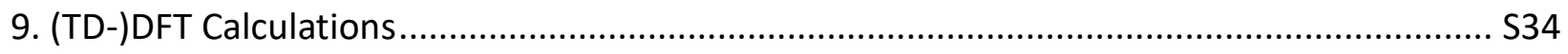

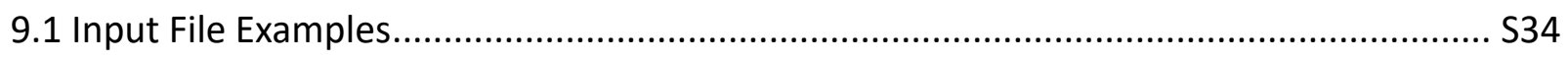

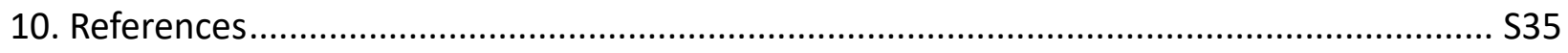




\section{NMR Spectroscopic Data}

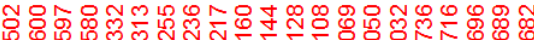

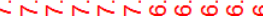
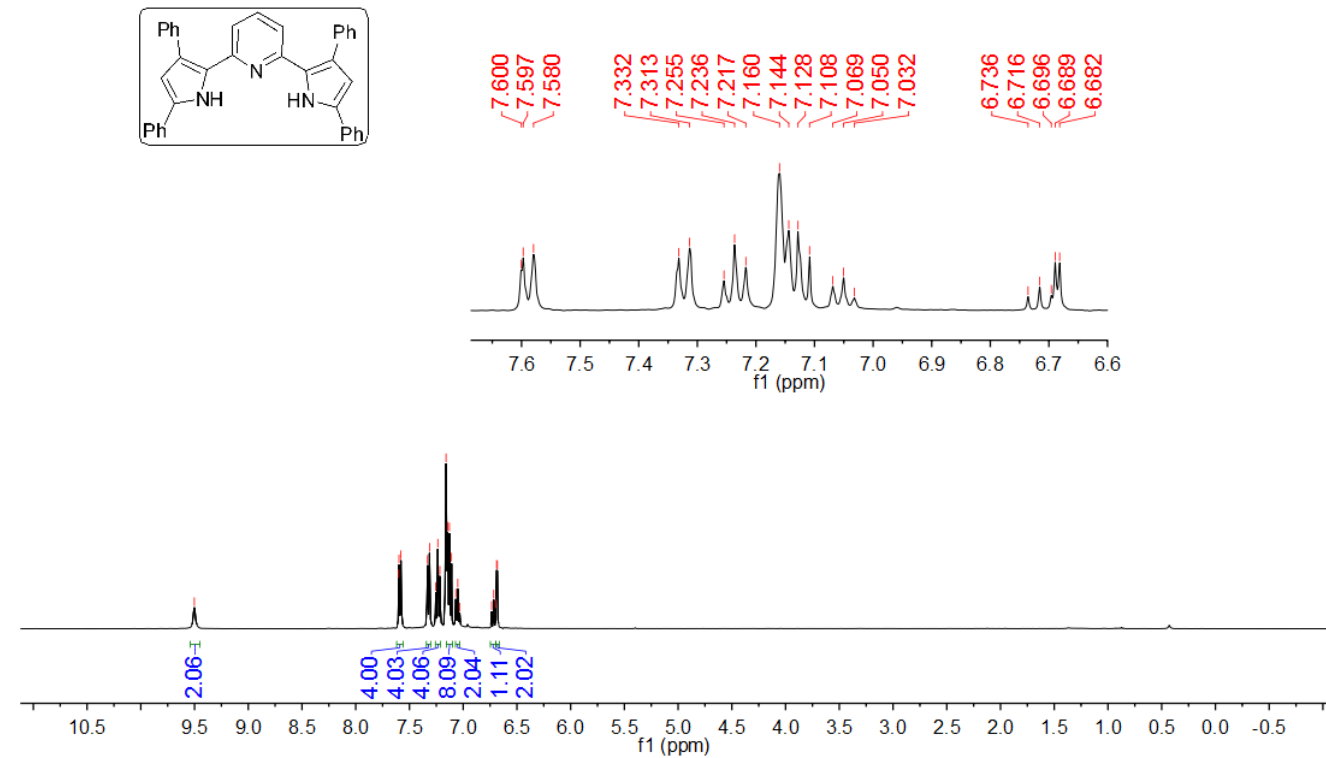

Figure S1. ${ }^{1} \mathrm{H}$ NMR spectrum of $\mathrm{H}_{2}{ }^{\mathrm{Ph} P D P}{ }^{\mathrm{Ph}}$ in benzene- $d_{6}$.

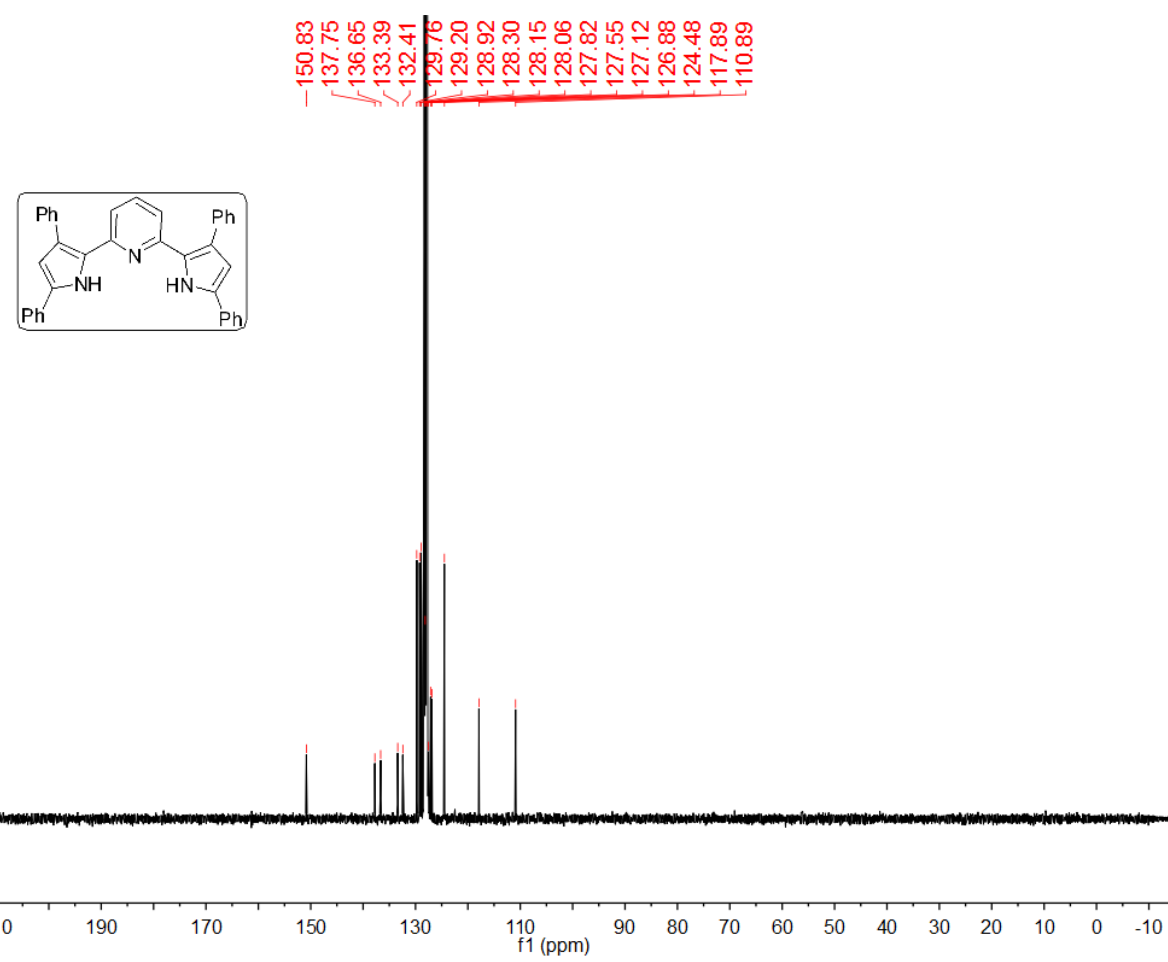

Figure S2. ${ }^{13} \mathrm{C}\left\{{ }^{1} \mathrm{H}\right\}$ NMR spectrum of $\mathrm{H}_{2}{ }^{\mathrm{Ph}} \mathrm{PDP}{ }^{\mathrm{Ph}}$ in benzene- $d_{6}$. 


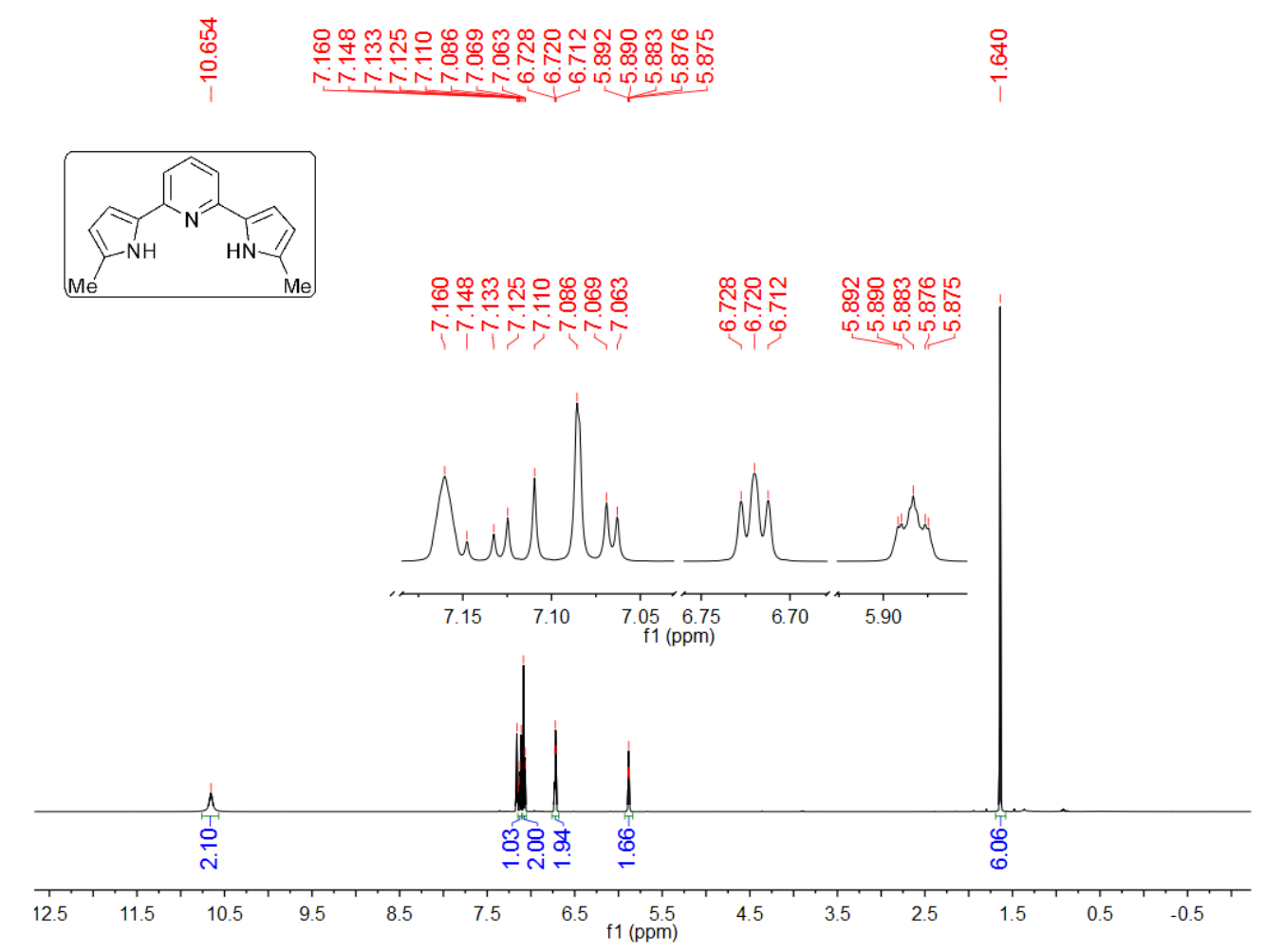

Figure S3. ${ }^{1} \mathrm{H}$ NMR spectrum of $\mathrm{H}_{2}{ }^{\mathrm{Me}} \mathrm{PDP} \mathrm{P}^{\mathrm{H}}$ in benzene- $d_{6}$.
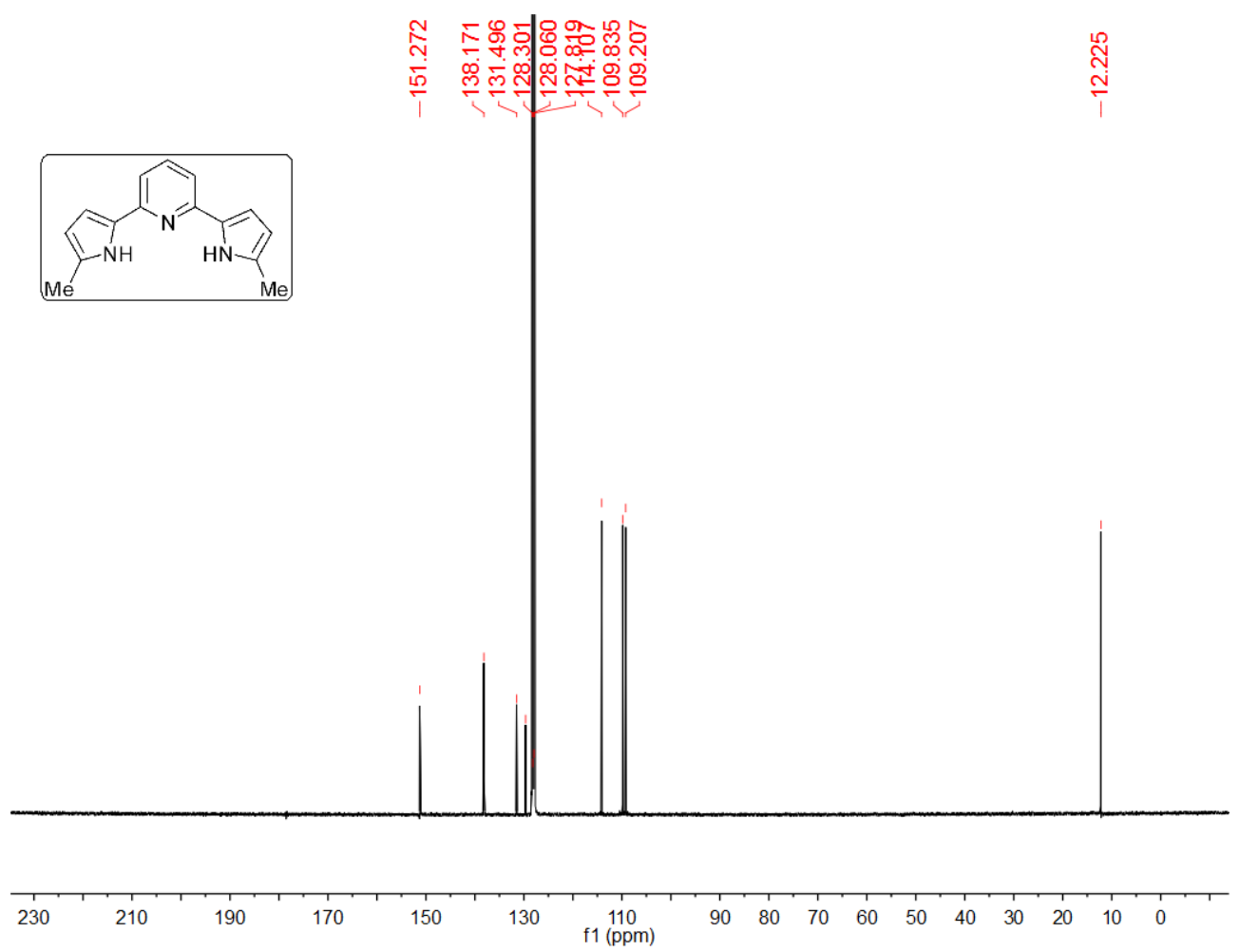

Figure S4. ${ }^{13} \mathrm{C}\left\{{ }^{1} \mathrm{H}\right\}$ NMR spectrum of $\mathrm{H}_{2}{ }^{\text {MePDP }}{ }^{\mathrm{H}}$ in benzene- $d_{6}$. 

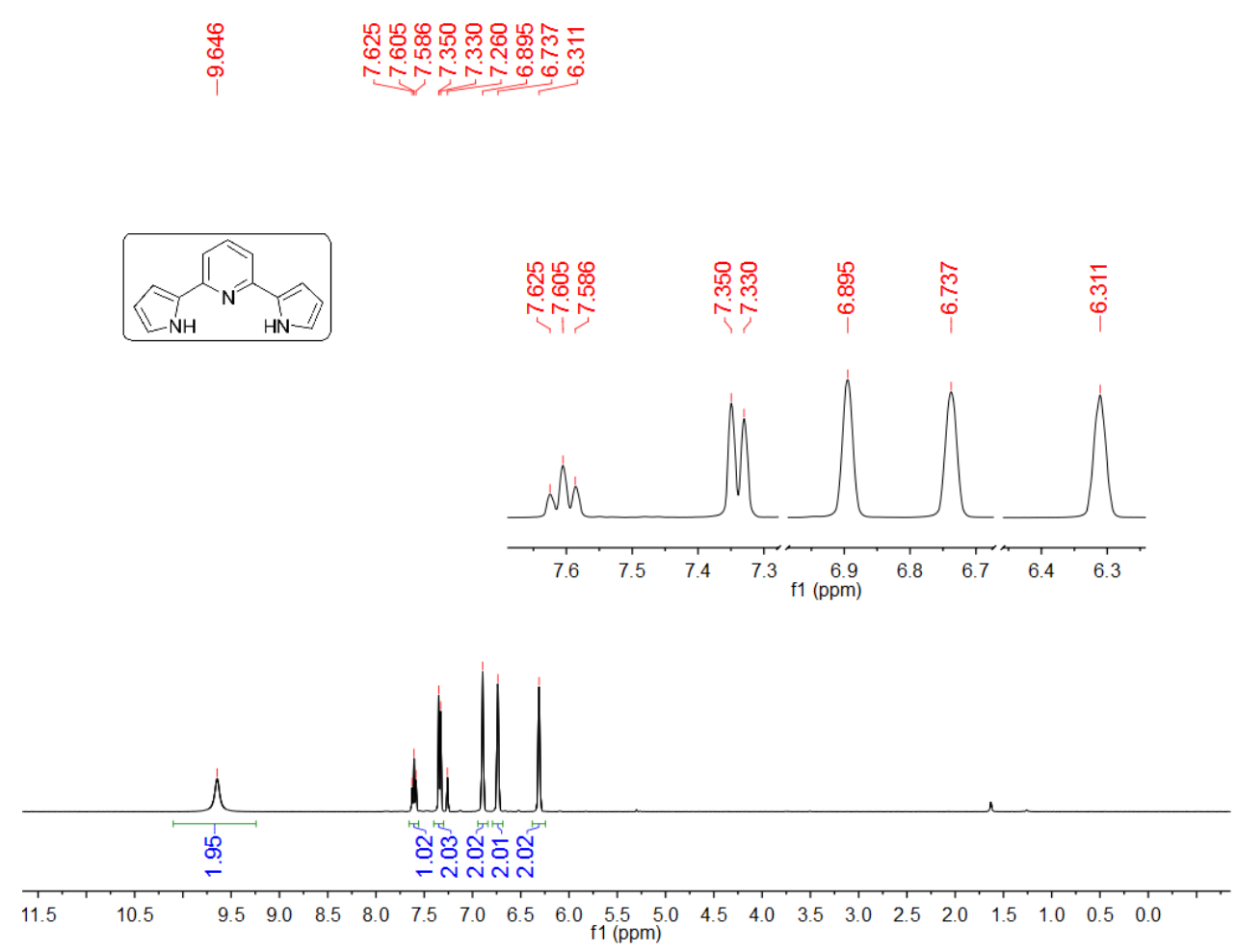

Figure S5. ${ }^{1} \mathrm{H}$ NMR spectrum of $\mathrm{H}_{2}{ }^{\mathrm{H} P D P H}$ in chloroform- $d$.
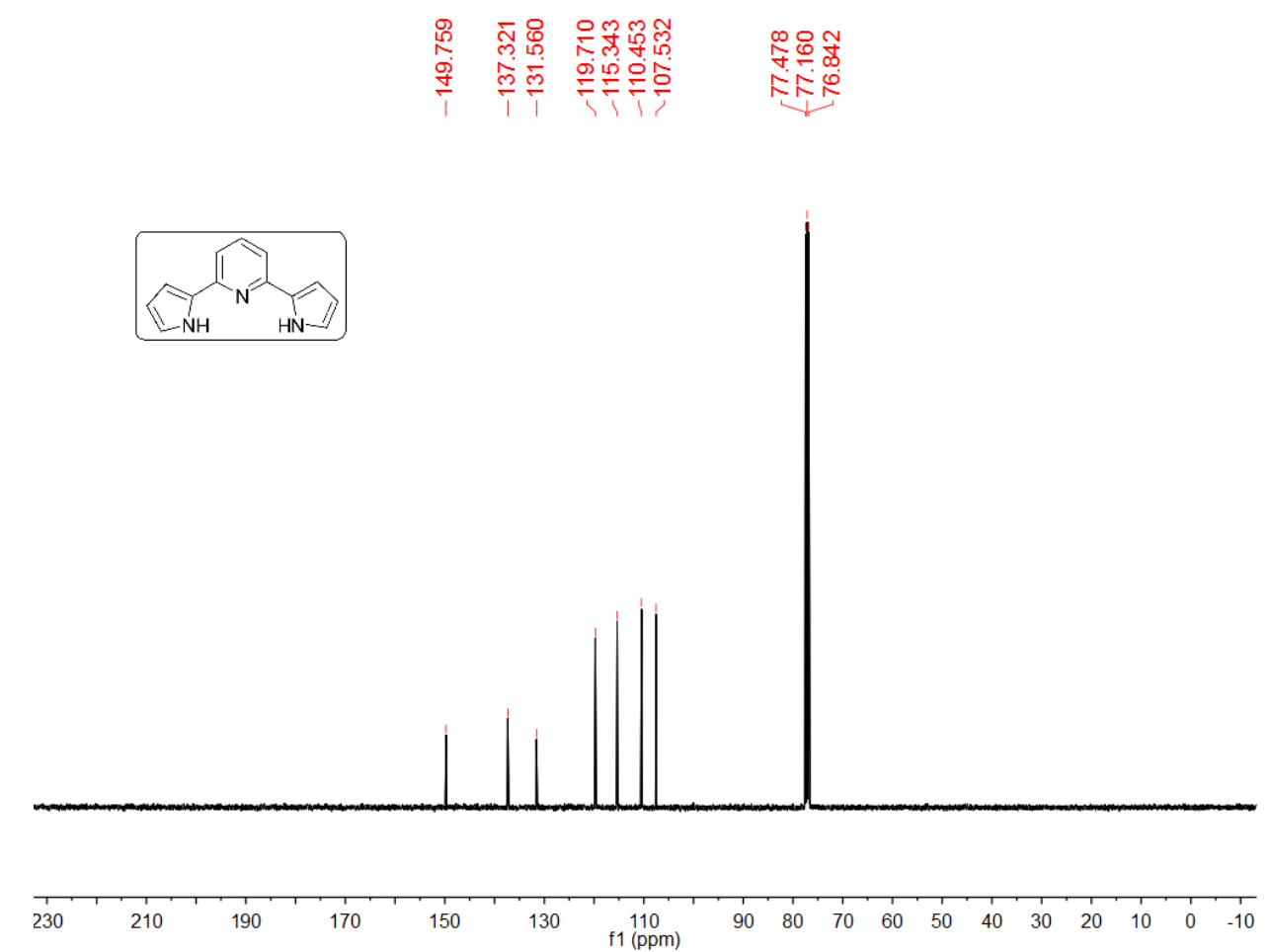

Figure S6. ${ }^{13} \mathrm{C}\left\{{ }^{1} \mathrm{H}\right\}$ NMR spectrum of $\mathrm{H}_{2}{ }^{\mathrm{H}}{ }^{\mathrm{P} D P} \mathrm{P}^{\mathrm{H}}$ in chloroform-d. 

$\underset{\frac{1}{0}}{\stackrel{1}{0}}$
تِ

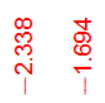

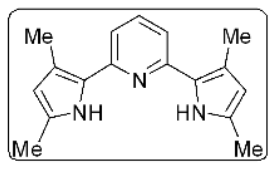

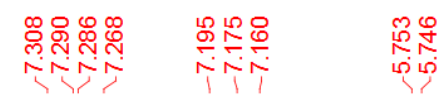
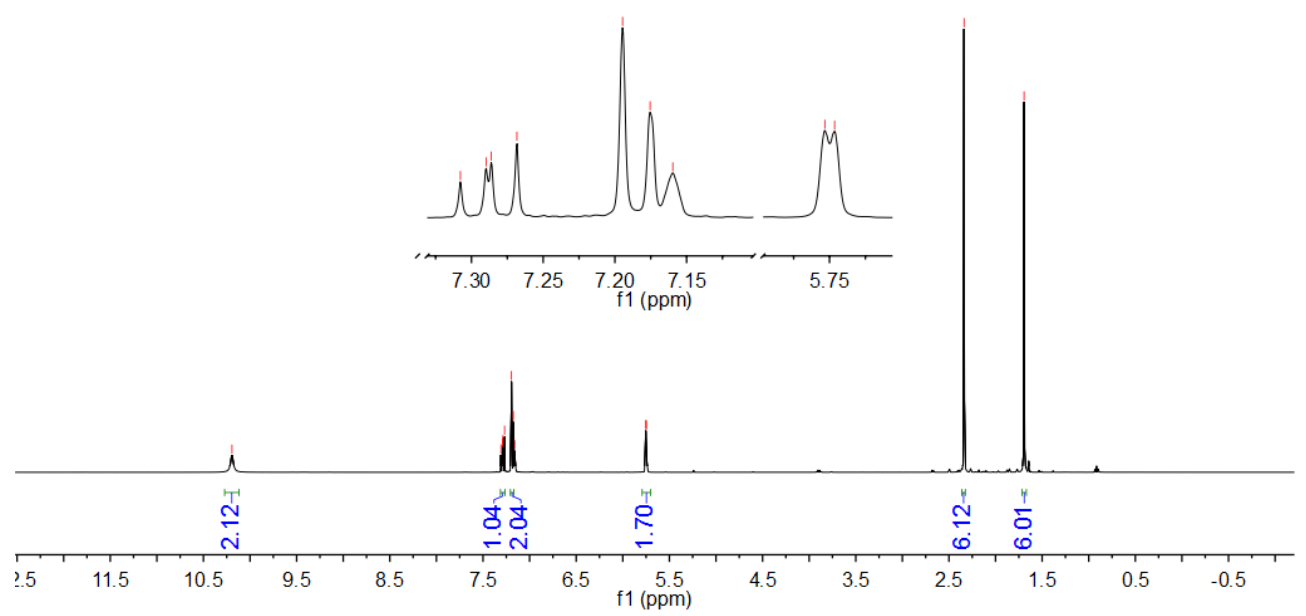

Figure S7. ${ }^{1} \mathrm{H}$ NMR spectrum of $\mathrm{H}_{2}{ }^{\mathrm{Me}}$ PDPMe in benzene- $d_{6}$.
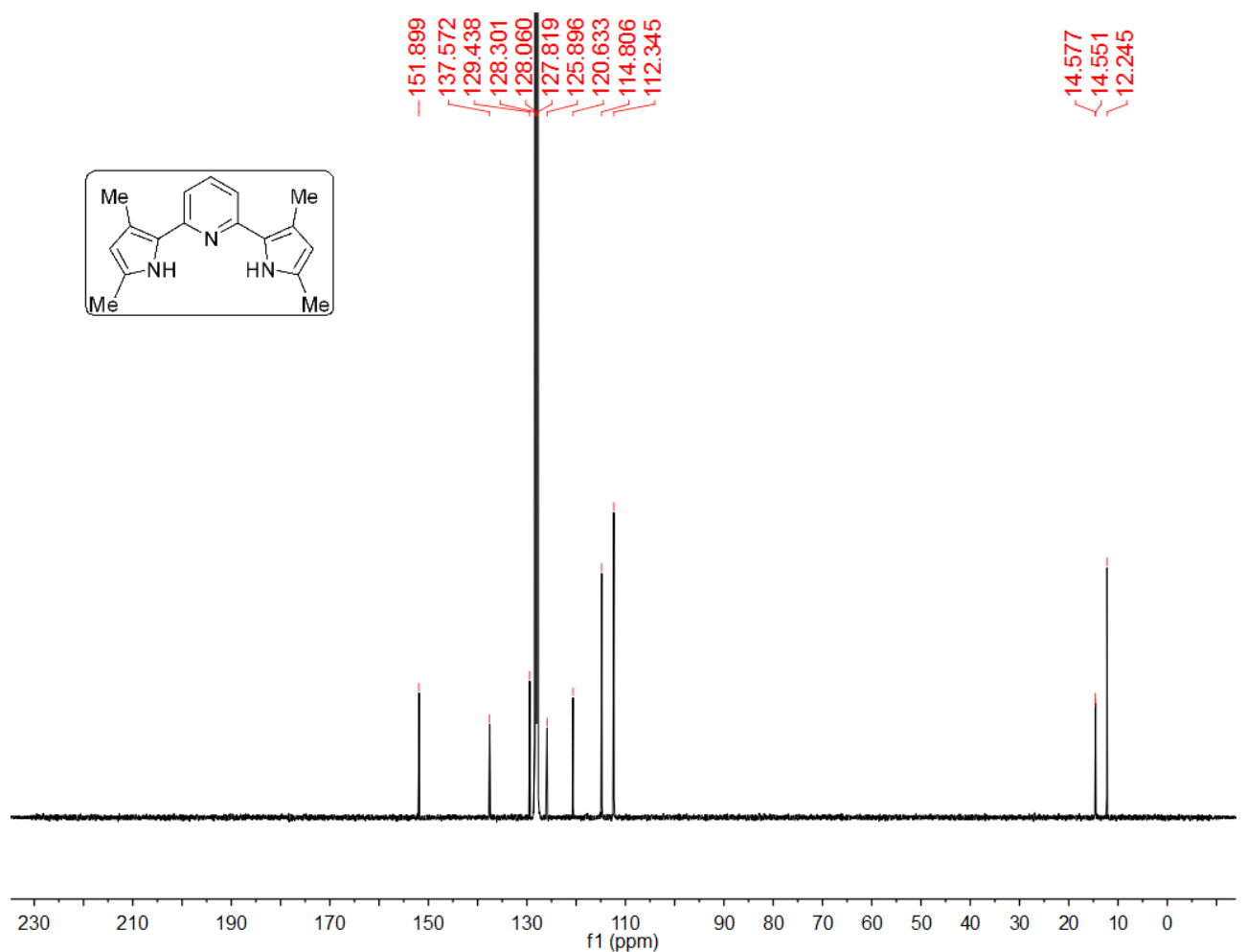

Figure S8. ${ }^{13} \mathrm{C}\left\{{ }^{1} \mathrm{H}\right\}$ NMR spectrum of $\mathrm{H}_{2}{ }^{\text {MePDPMe }}$ in benzene- $d_{6}$. 

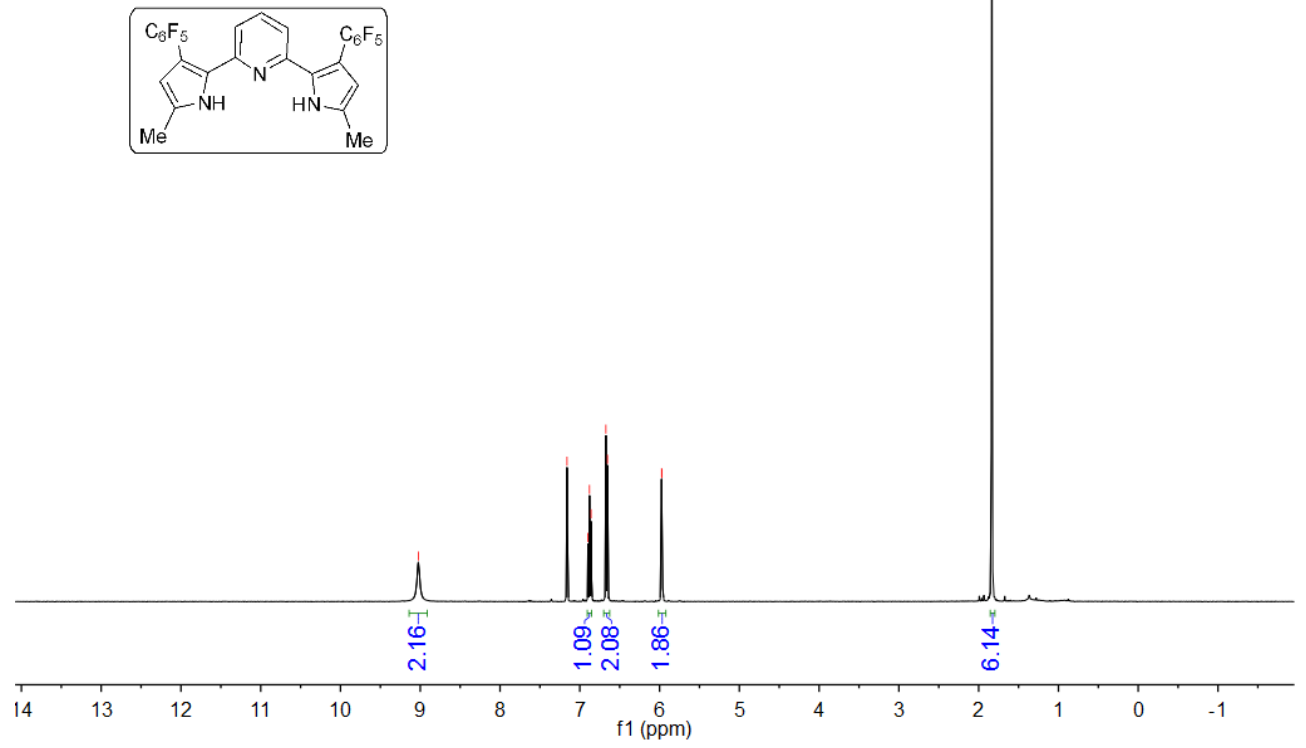

Figure S9. ${ }^{1} \mathrm{H}$ NMR spectrum of $\mathrm{H}_{2}{ }^{\text {MePDP }}{ }^{\mathrm{C} 6 F 5}$ in benzene- $d_{6}$.

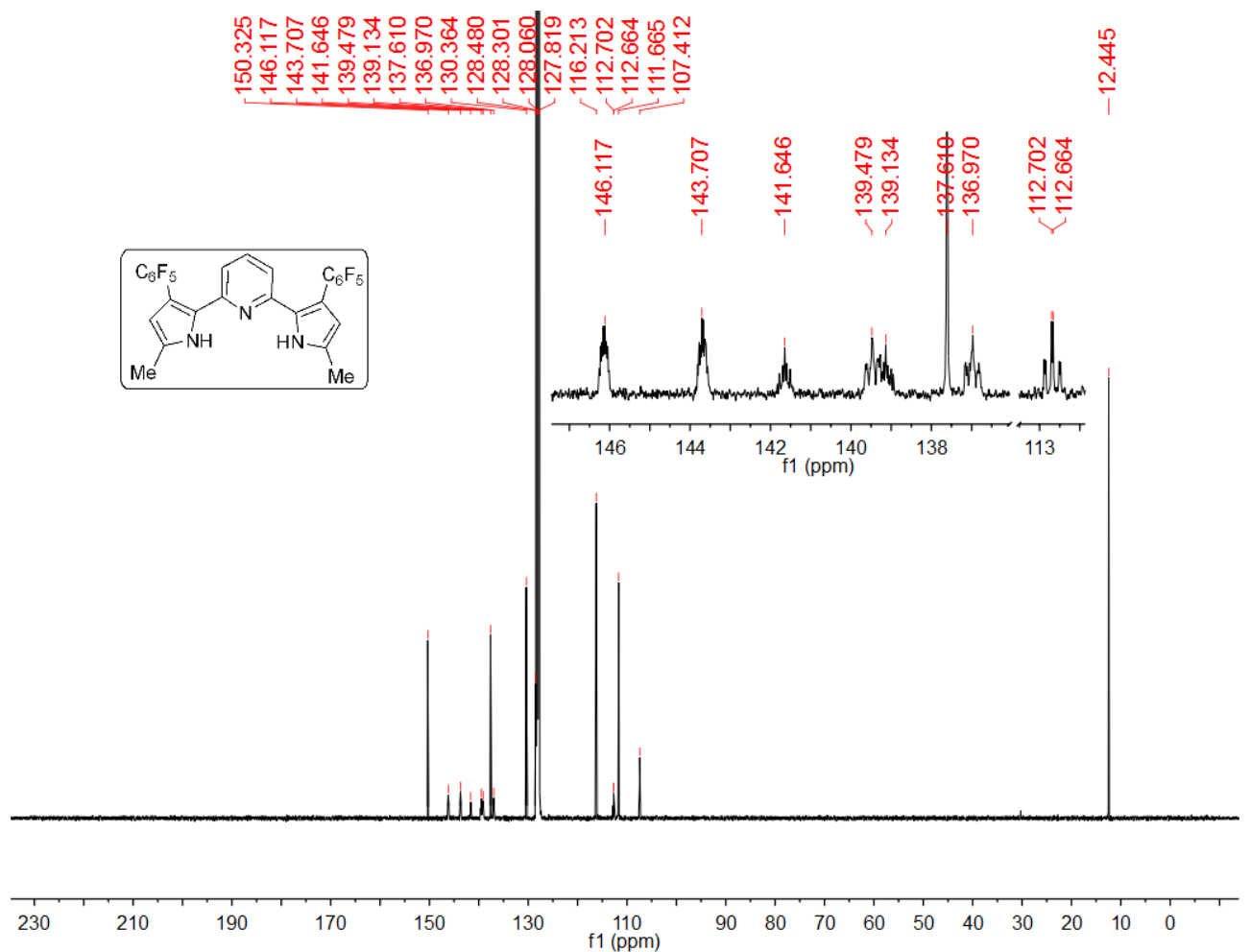

Figure S10. ${ }^{13} \mathrm{C}\left\{{ }^{1} \mathrm{H}\right\}$ NMR spectrum of $\mathrm{H}_{2}{ }^{\text {MePDPC6F5 }}$ in benzene- $d_{6}$. 

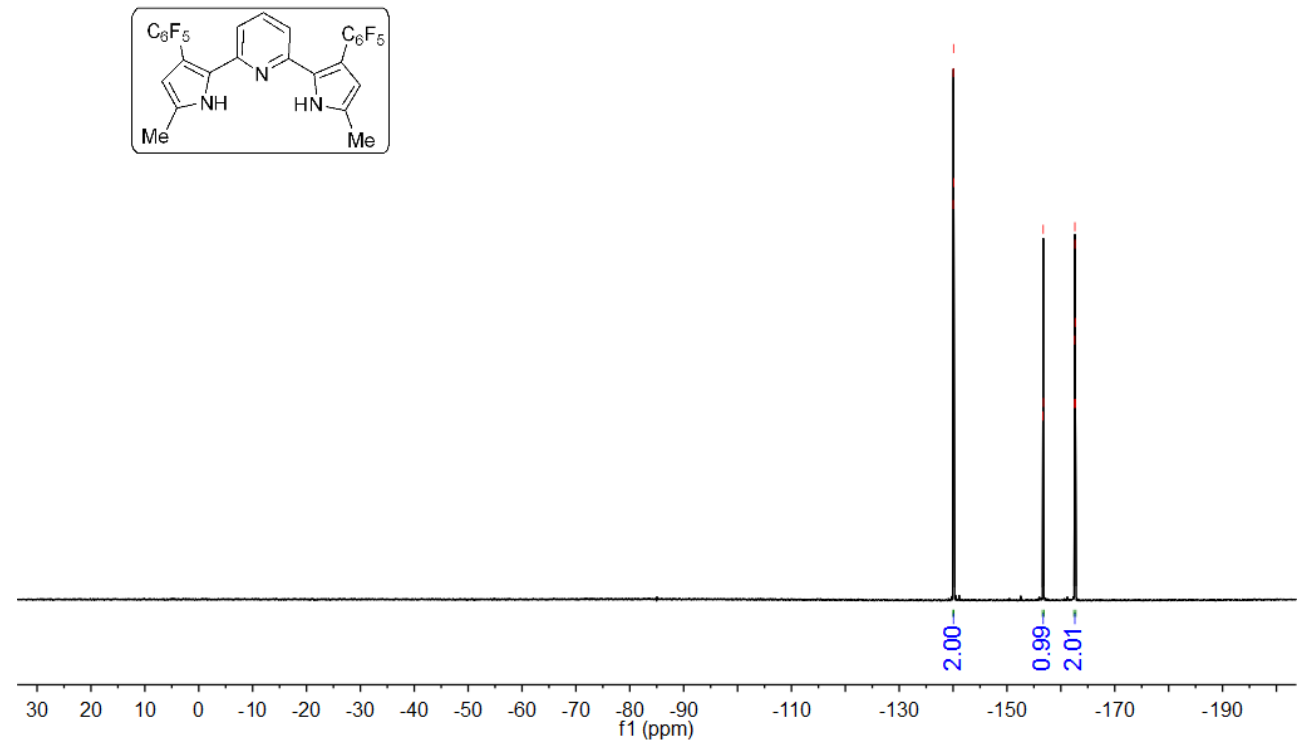

Figure S11. ${ }^{19} \mathrm{~F}$ NMR spectrum of $\mathrm{H}_{2}{ }^{\mathrm{Me}} \mathrm{PDP} \mathrm{C}^{\mathrm{C} F 5}$ in benzene- $d_{6}$.
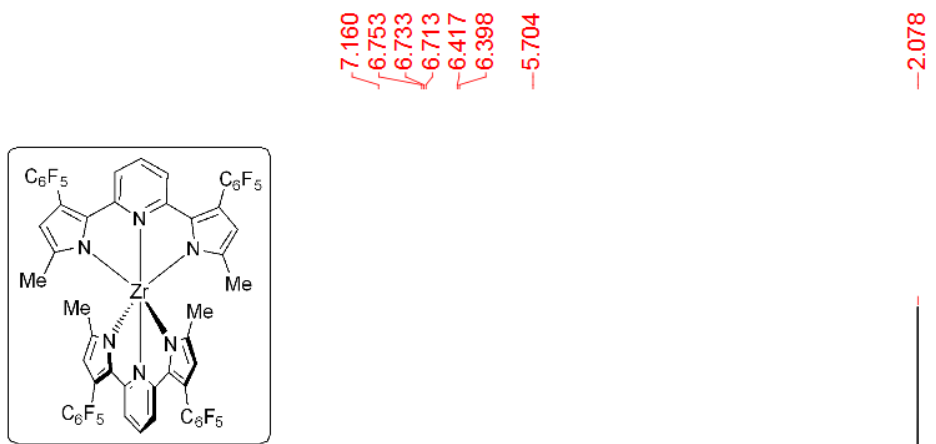

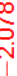

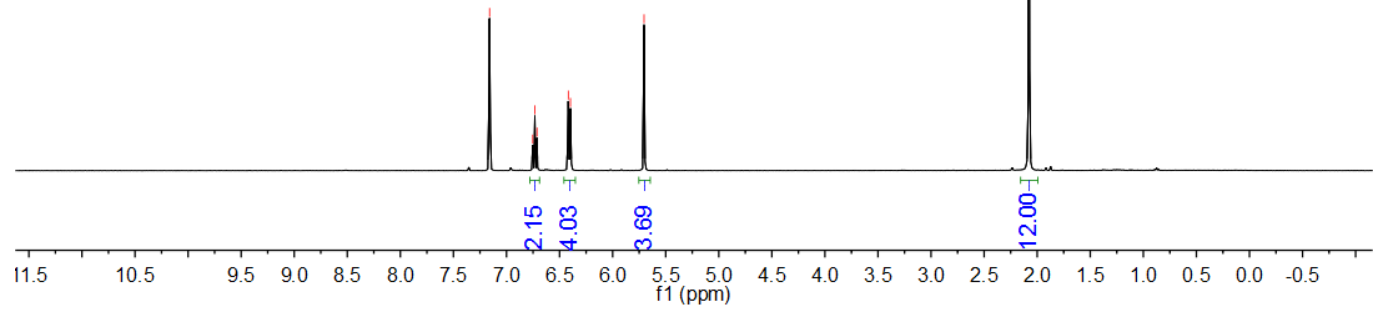

Figure S12. ${ }^{1} \mathrm{H}$ NMR spectrum of $\mathrm{Zr}\left({ }^{\mathrm{Me}} \mathrm{PDP}{ }^{\mathrm{C} 6 F 5}\right)_{2}$ in benzene- $d_{6}$. 

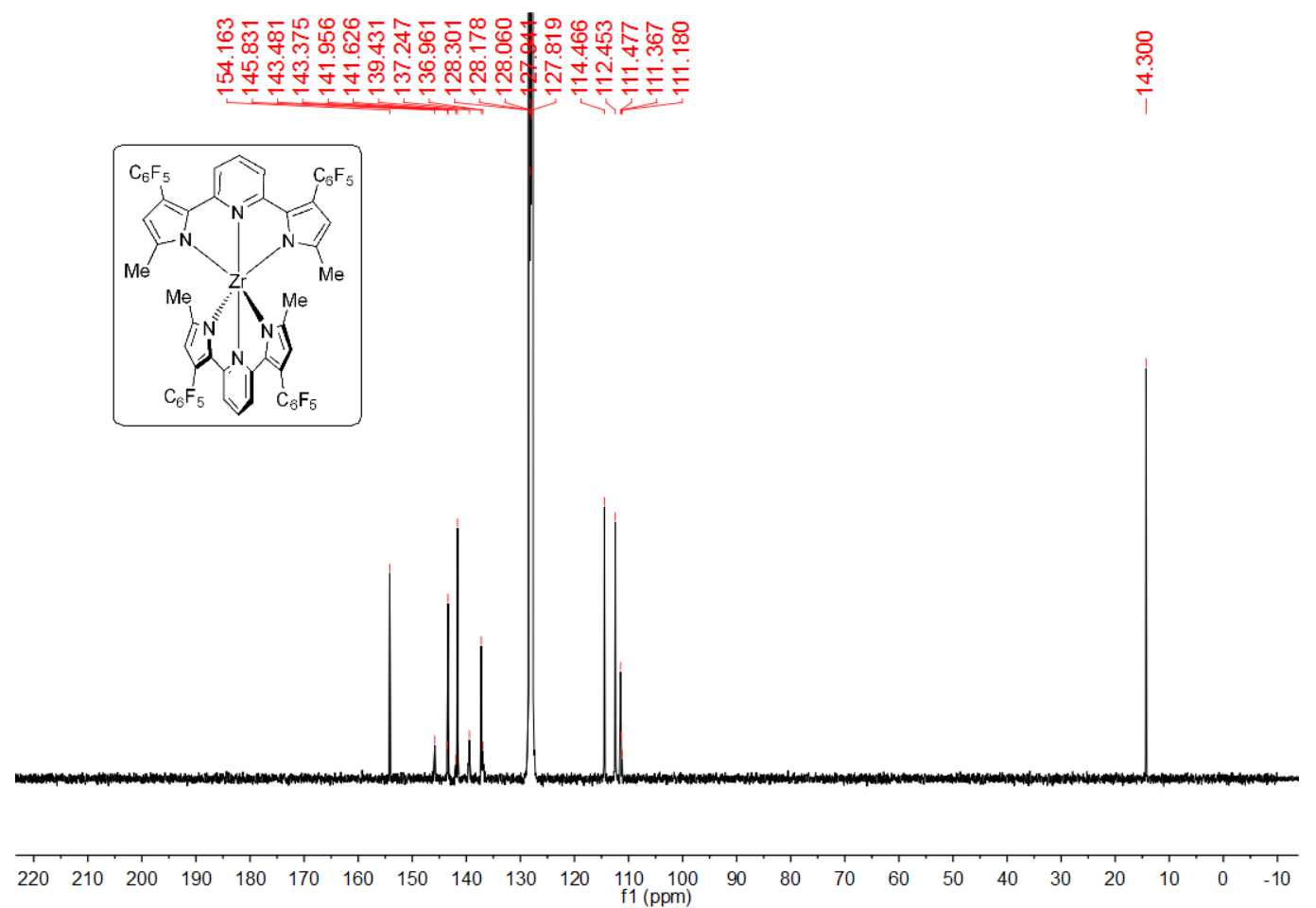

Figure S13. ${ }^{13} \mathrm{C}\left\{{ }^{1} \mathrm{H}\right\}$ NMR spectrum of $\mathrm{Zr}\left({ }^{\left({ }^{M e P D P}\right.}{ }^{\mathrm{C} 6 F 5}\right)_{2}$ in benzene- $d_{6}$.
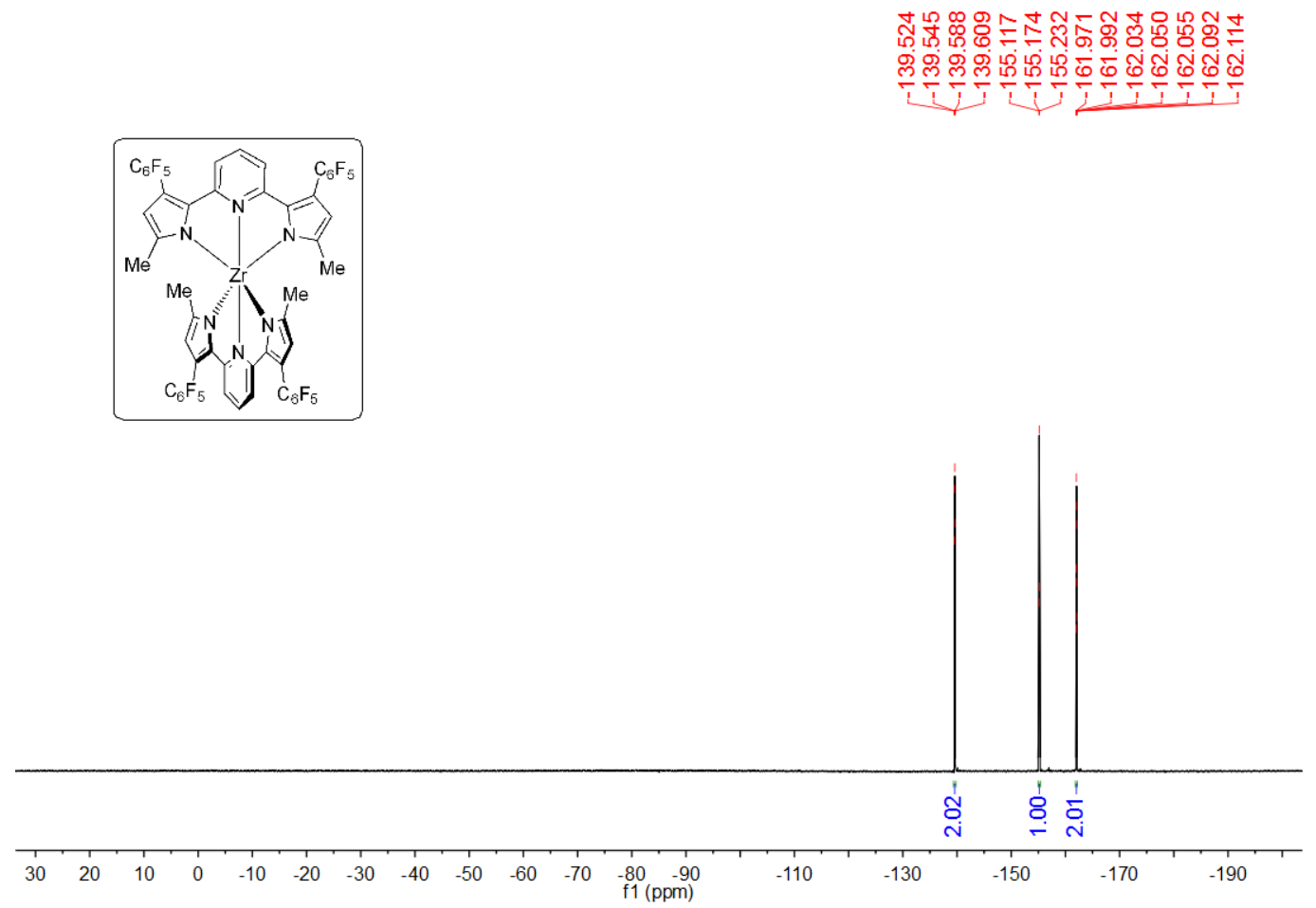

Figure S14. ${ }^{19} \mathrm{~F}$ NMR spectrum of $\mathrm{Zr}\left({ }^{\mathrm{Me} P D P}{ }^{\mathrm{C} 6 F 5}\right)_{2}$ in benzene- $d_{6}$. 

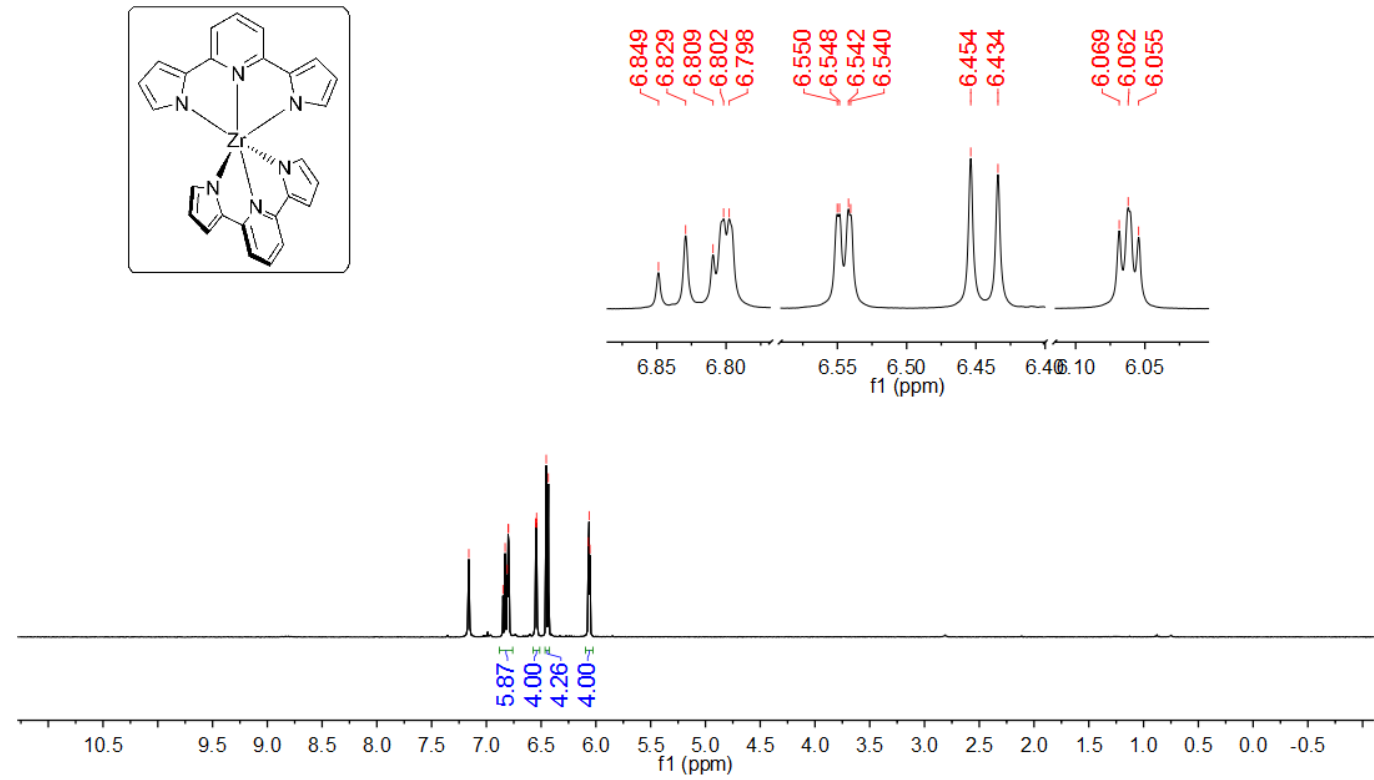

Figure S15. ${ }^{1} \mathrm{H}$ NMR spectrum of $\mathrm{Zr}\left({ }^{\mathrm{H} P D P}{ }^{\mathrm{H}}\right)_{2}$ in benzene- $d_{6}$.

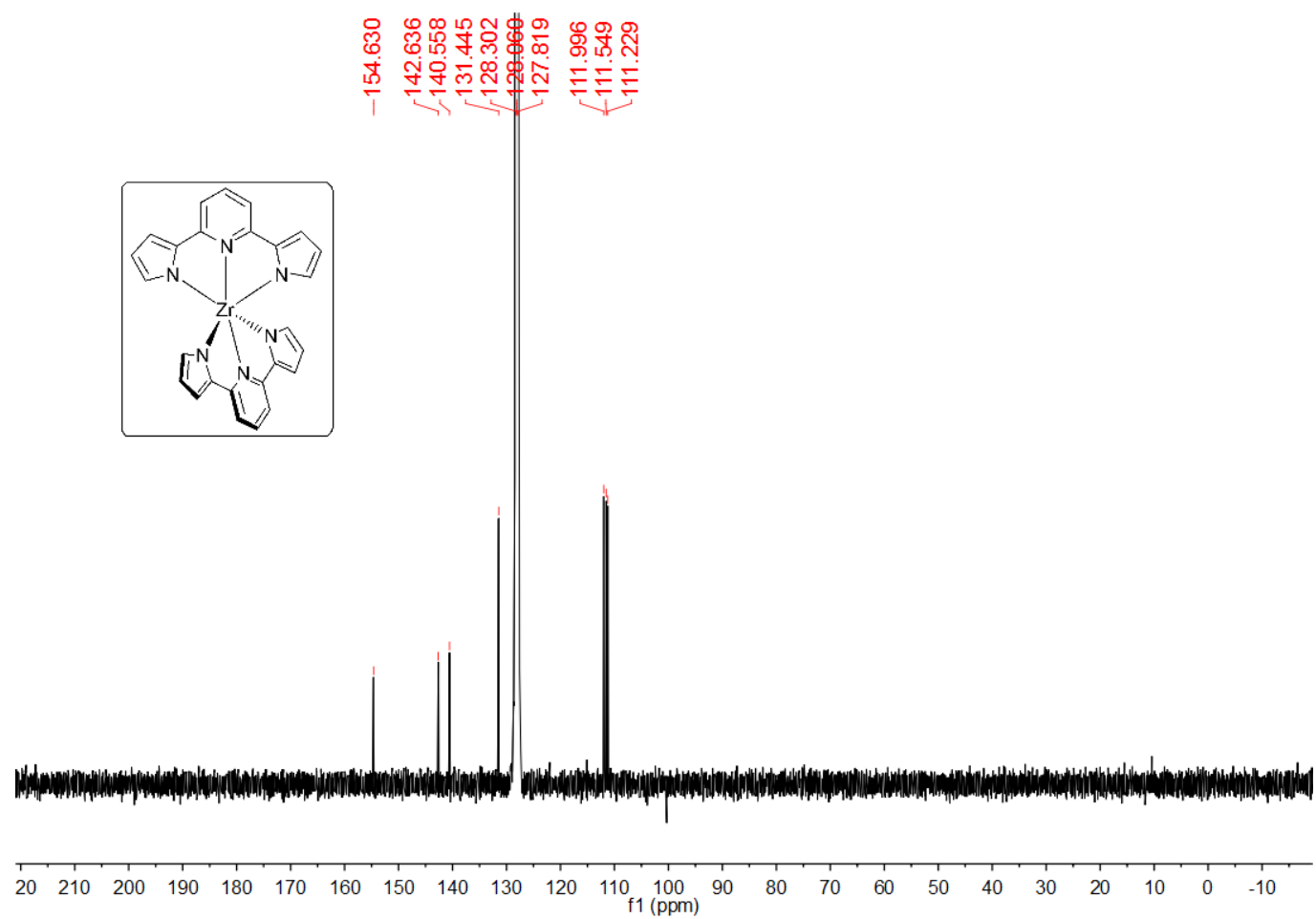

Figure S16. ${ }^{13} \mathrm{C}\left\{{ }^{1} \mathrm{H}\right\}$ NMR spectrum of $\mathrm{Zr}\left({ }^{\mathrm{H} P D P}{ }^{\mathrm{H}}\right)_{2}$ in benzene- $d_{6}$. 


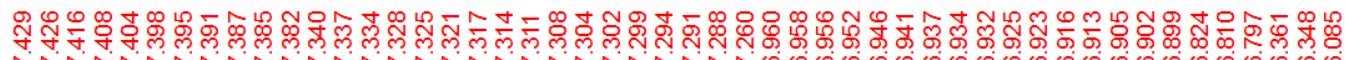

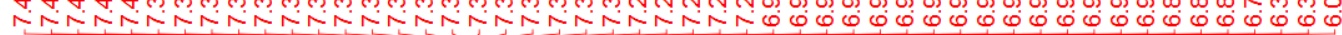
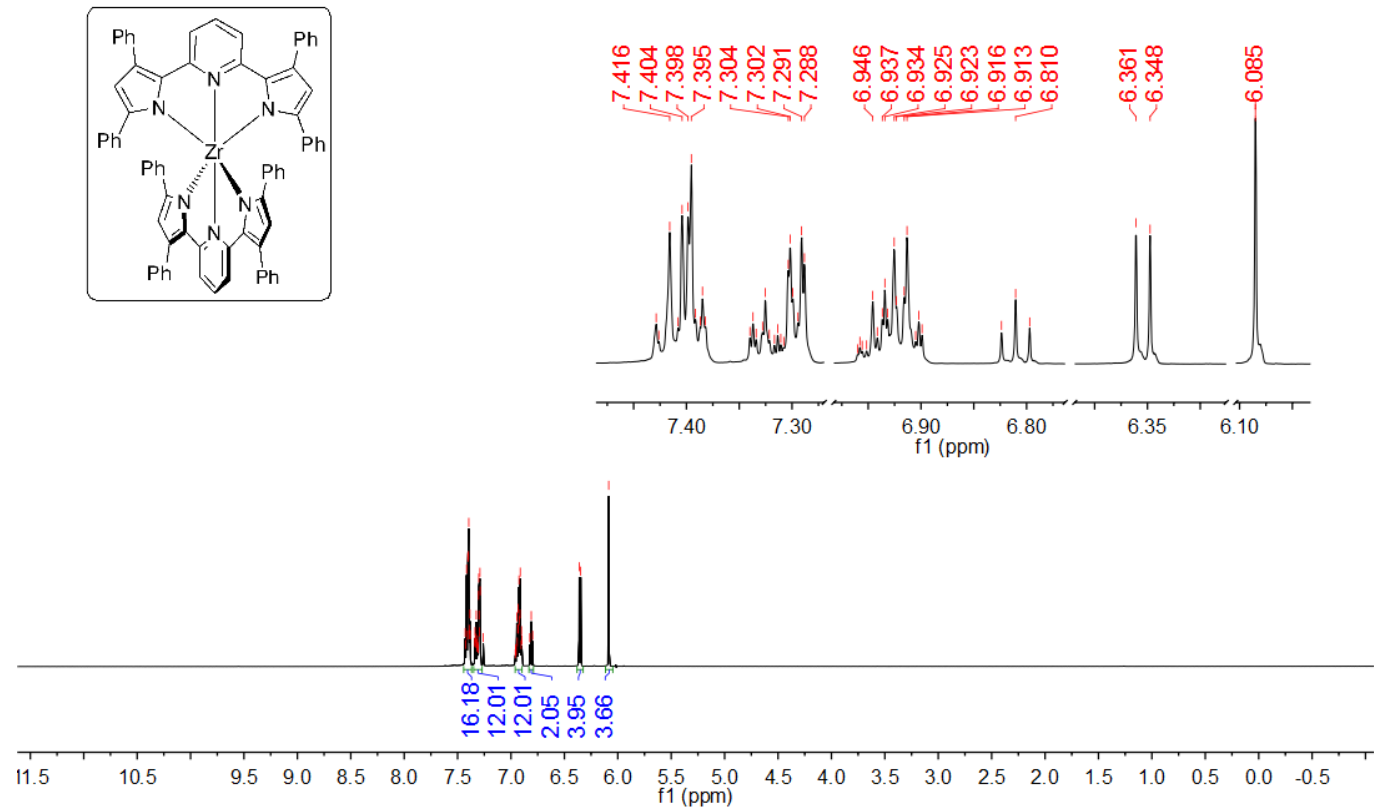

Figure S17. ${ }^{1} \mathrm{H}$ NMR spectrum of $\mathrm{Zr}\left({ }^{\mathrm{Ph} P D P}{ }^{\mathrm{Ph}}\right)_{2}$ in chloroform- $d$.
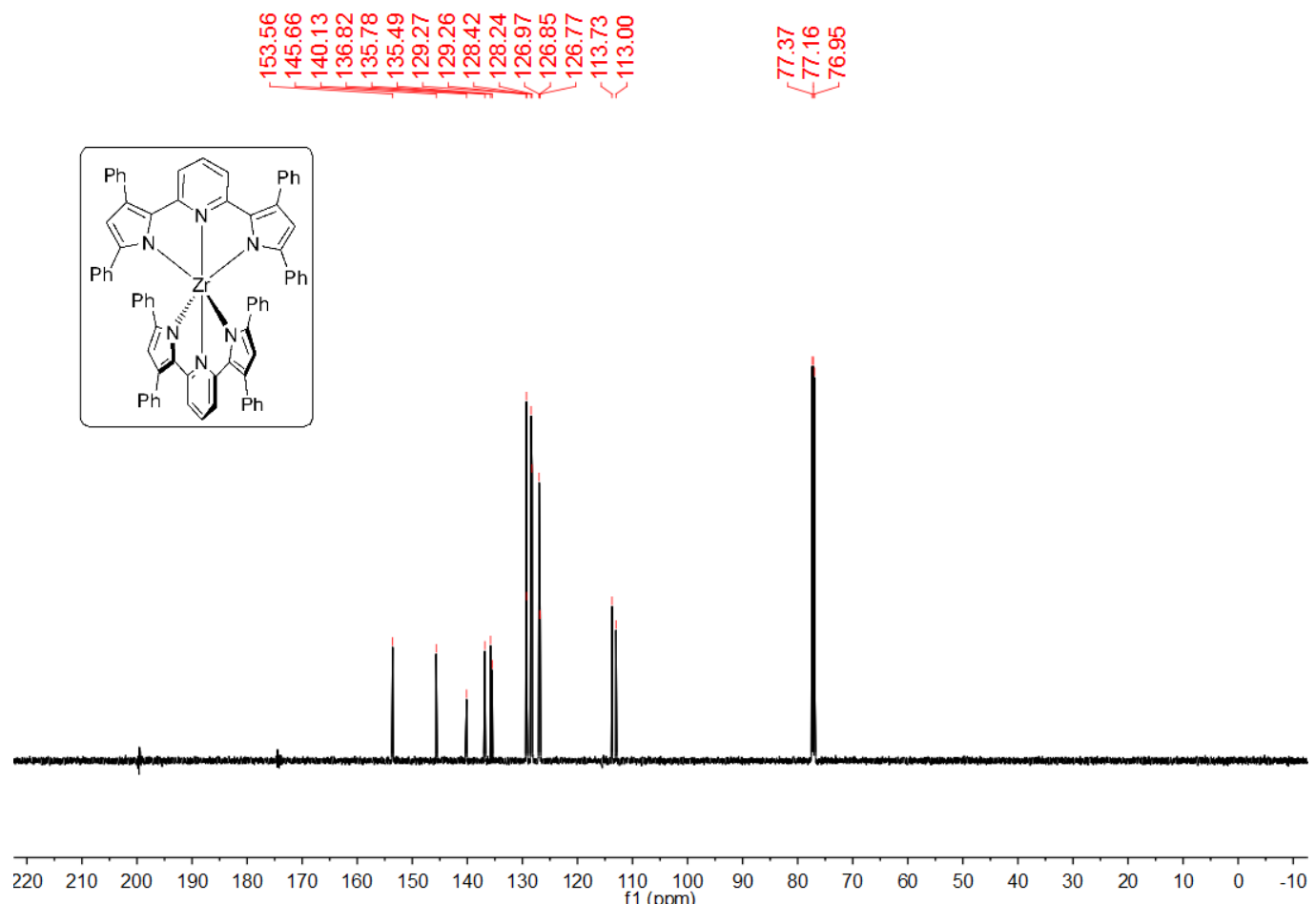

Figure S18. ${ }^{13} \mathrm{C}\left\{{ }^{1} \mathrm{H}\right\}$ NMR spectrum of $\mathrm{Zr}\left({ }^{\mathrm{Ph} P D P}{ }^{\mathrm{Ph}}\right)_{2}$ in chloroform-d. 


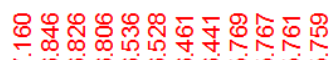

N

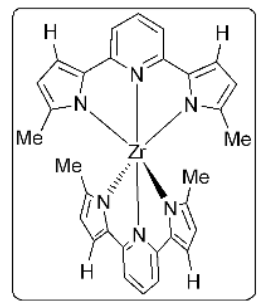

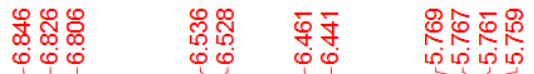
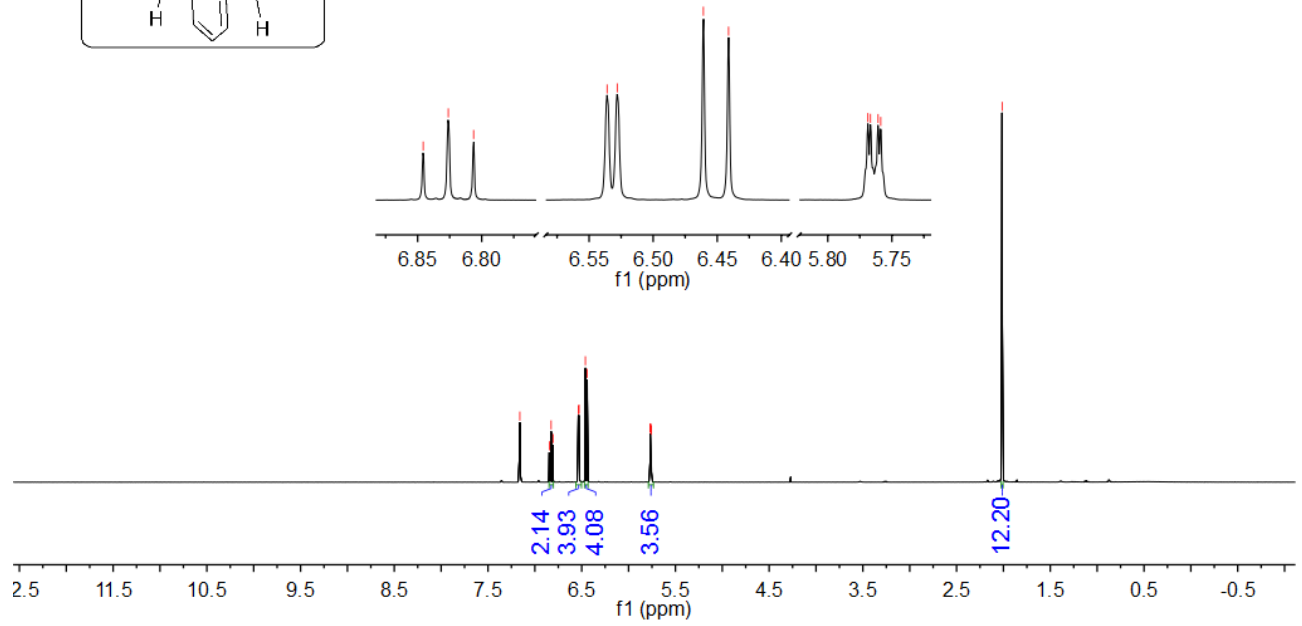

Figure S19. ${ }^{1} \mathrm{H}$ NMR spectrum of $\mathrm{Zr}\left({ }^{\mathrm{Me}} \mathrm{PDP}^{\mathrm{H}}\right)_{2}$ in benzene- $d_{6}$.

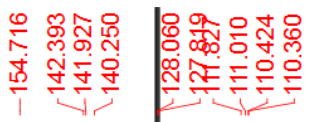

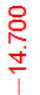

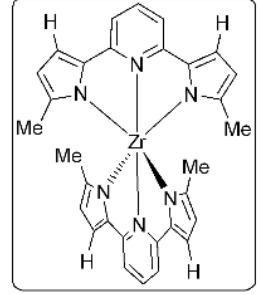

广

$\stackrel{\text { ì }}{\stackrel{4}{a}}$

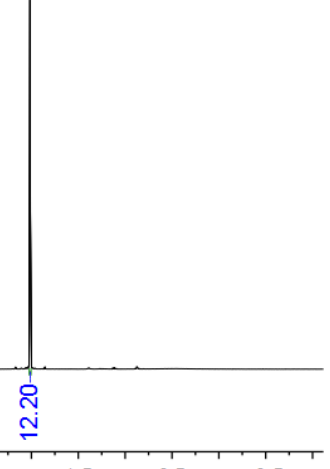




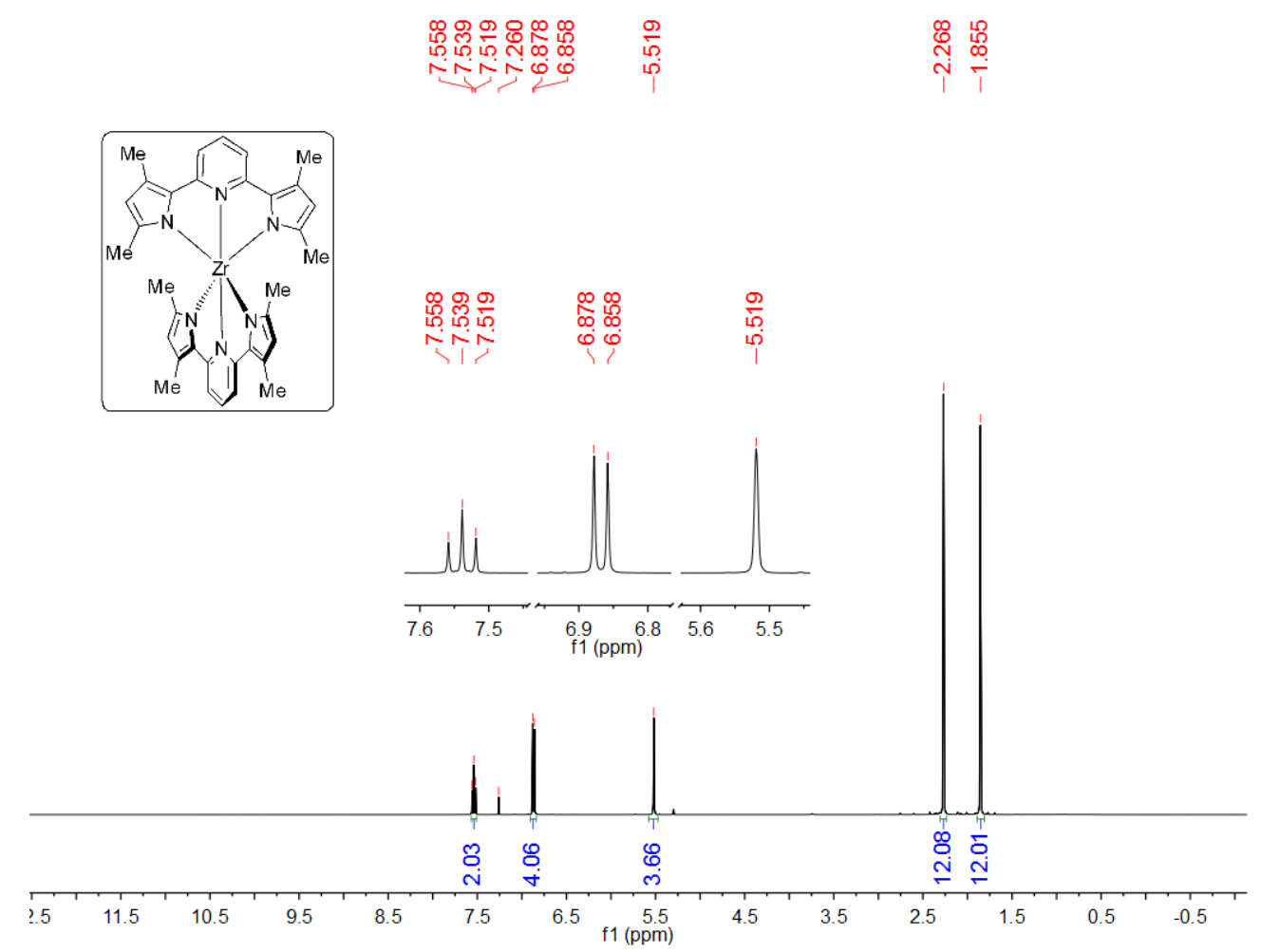

Figure S21. ${ }^{1} \mathrm{H}$ NMR spectrum of $\mathrm{Zr}\left({ }^{\mathrm{Me}} \mathrm{PDP}^{\mathrm{Me}}\right)_{2}$ in chloroform- $d$.
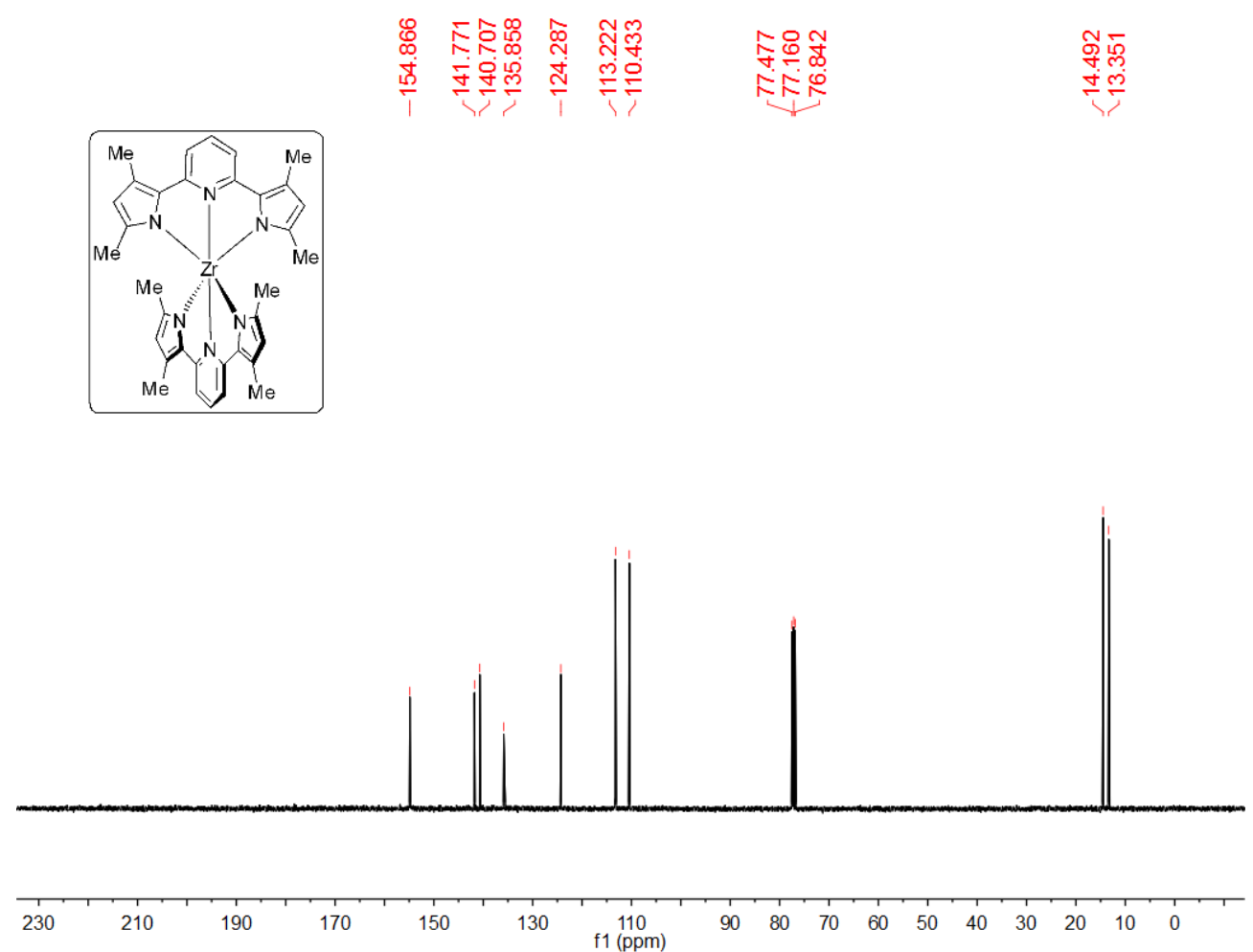

Figure S22. ${ }^{13} \mathrm{C}\left\{{ }^{1} \mathrm{H}\right\}$ NMR spectrum of $\mathrm{Zr}\left({ }^{\text {MePDPMe }}\right)_{2}$ in chloroform- $d$. 


\section{X-Ray Crystallography.}

Single crystals suitable for X-ray diffraction were coated with polyisobutylene oil (Sigma-Aldrich) in a drybox, transferred to a nylon loop, and then quickly mounted on the goniometer head of a Bruker AXS D8 Venture fixed-chi X-ray diffractometer equipped with a Triumph monochromator, a Mo K $\alpha$ radiation source $(I=0.71073 \AA$ ) , and a PHOTON 100 CMOS detector. The samples were cooled to $100 \mathrm{~K}$ with an Oxford Cryostream 700 system and optically aligned. The APEX3 software program (version 2016.9-0) ${ }^{1}$ was used for diffractometer control, preliminary frame scans, indexing, orientation matrix calculations, least-squares refinement of cell parameters, and the data collection. Three sets of 12 frames each were collected using the omega scan method with a $10 \mathrm{~s}$ exposure time. Integration of these frames followed by reflection indexing and leastsquares refinement produced a crystal orientation matrix for the crystal lattice that was used for the structural analysis. The data collection strategy was optimized for completeness and redundancy using the Bruker COSMO software suite. The space group was identified, and the data were processed using the Bruker SAINT+ program and corrected for absorption using SADABS. The structures were solved using direct methods (SHELXS) completed by subsequent Fourier synthesis and refined by full-matrix least-squares procedures using the programs provided by SHELXL-2014. $^{2}$ 
Table S1. Crystallographic Data Collection and Refinement Details for $\operatorname{Zr}\left({ }^{\mathrm{Me} P D P} \mathrm{Pe}_{2}\right)_{2}, \mathrm{Zr}\left({ }^{\mathrm{Me} P D P}{ }^{\mathrm{C} 6 F 5}\right)_{2} \cdot \mathrm{Et}_{2} \mathrm{O}$, and $\mathrm{Zr}\left({ }^{\left({ }^{M e P D P H}\right.}\right)_{2} \cdot \mathrm{Et}_{2} \mathrm{O}$.

\begin{tabular}{|c|c|c|c|}
\hline & $\mathrm{Zr}\left({ }^{\text {MePDPMe }}\right)_{2}$ & $\mathrm{Zr}\left({ }^{\mathrm{Me}} \mathrm{PDP} \mathrm{C6F5}_{2}\right.$ & $\mathrm{Zr}\left({ }^{\left({ }^{2}\right.} \mathrm{PDP}^{\mathrm{H}}\right)_{2}$ \\
\hline Chem. formula & $\left(\mathrm{C}_{17} \mathrm{H}_{17} \mathrm{~N}_{3}\right)_{2} \mathrm{Zr} \cdot 2 \mathrm{THF}$ & $\left(\mathrm{C}_{27} \mathrm{H}_{11} \mathrm{~F}_{10} \mathrm{~N}_{3}\right)_{2} \mathrm{Zr} \cdot \mathrm{Et}_{2} \mathrm{O}$ & $\left(\mathrm{C}_{15} \mathrm{H}_{13} \mathrm{~N}_{3}\right)_{2} \mathrm{Zr} \cdot \mathrm{Et}_{2} \mathrm{O}$ \\
\hline Cryst size, $\mathrm{mm}^{3}$ & $0.082 \times 0.214 \times 0.593$ & $0.182 \times 0.259 \times 0.262$ & $0.114 \times 0.402 \times 0.407$ \\
\hline $\mathrm{Fw}, \mathrm{g} / \mathrm{mol}$ & 762.10 & 1300.11 & 635.91 \\
\hline Space group & $\begin{array}{l}\mathrm{P} 2_{1} / \mathrm{n} \text { (non-standard } \\
\text { setting of } \mathrm{P} 2_{1} / \mathrm{c} \text { (No. } \\
\text { 14)) }\end{array}$ & $P(-1)($ No. 2$)$ & Pbca (No. 61) \\
\hline $\mathrm{a}, \AA$ & $18.0253(8)$ & $15.4311(7)$ & $16.0187(7)$ \\
\hline$b, \AA$ & $9.1387(4)$ & $15.7762(8)$ & $14.0449(7)$ \\
\hline$c, \AA$ & $22.8408(10)$ & $23.3019(11)$ & $26.9193(13)$ \\
\hline$\alpha, \operatorname{deg}$ & 90 & $89.2542(14)$ & 90 \\
\hline$\beta$, deg & $102.0110(14)$ & $87.0739(14)$ & 90 \\
\hline$\gamma$, deg & 90 & $64.1745(13)$ & 90 \\
\hline $\mathrm{V}, \AA$ & $3680.1(2)$ & $5099.2(4)$ & $6056.3(5)$ \\
\hline z & 4 & 4 & 8 \\
\hline $\mathrm{T}, \mathrm{K}$ & $100(2)$ & $100(2)$ & $100(2)$ \\
\hline$\rho$ calcd, $\mathrm{g} \mathrm{cm}^{-3}$ & 1.375 & 1.694 & 1.395 \\
\hline Reflns collected $/ 2 \Theta_{\max }$ & $70900 / 55.00$ & $101562 / 55.00$ & $31072 / 55.04$ \\
\hline 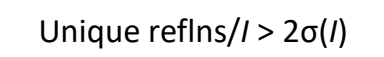 & $8432 / 6893$ & 23399/17039 & $6961 / 4478$ \\
\hline No. of params/restraints & $468 / 0$ & $1514 / 0$ & $385 / 0$ \\
\hline$\lambda, \AA$ & 0.71073 & 0.71073 & 0.71073 \\
\hline$R 1^{a} /$ goodness of fit ${ }^{b}$ & $0.0346 / 1.045$ & $0.0460 / 1.018$ & $0.0485 / 1.029$ \\
\hline $\operatorname{wR2}^{c}(I>2 \sigma(I))$ & 0.0742 & 0.0968 & 0.0817 \\
\hline Residual density, $\mathrm{e} \AA^{-3}$ & $+0.530 /-0.440$ & $+1.329 /-0.716$ & $+0.866 /-0.677$ \\
\hline
\end{tabular}


Table S2. Crystallographic Data Collection and Refinement Details for $\mathrm{Zr}\left({ }^{(\mathrm{h} P D P P h}\right)_{2} \cdot 2 \mathrm{Et}_{2} \mathrm{O}, \mathrm{Zr}\left({ }^{\mathrm{H} P D P}{ }^{\mathrm{H}}\right)_{2}$, and $\mathrm{Zr}\left({ }^{\mathrm{H} P D P}\right)_{2}(\text { thf })_{2}$.

\begin{tabular}{|c|c|c|c|}
\hline & $\mathrm{Zr}\left({ }^{\mathrm{Ph} P D P} \mathrm{Ph}_{2}\right.$ & $\mathrm{Zr}\left({ }^{\mathrm{H}} \mathrm{PDP}^{\mathrm{H}}\right)_{2}$ & $\mathrm{Zr}\left({ }^{(} \mathrm{PDP}{ }^{\mathrm{H}}\right)_{2}(\text { thf })_{2}$ \\
\hline Chem. formula & $\left(\mathrm{C}_{37} \mathrm{H}_{25} \mathrm{~N}_{3}\right)_{2} \mathrm{Zr} \cdot 2 \mathrm{OEt}{ }_{2}$ & $\left(\mathrm{C}_{12} \mathrm{H}_{9} \mathrm{~N}_{3}\right)_{2} \mathrm{Zr}$ & $\left(\mathrm{C}_{13} \mathrm{H}_{9} \mathrm{~N}_{3}\right)_{2} \mathrm{Zr}\left(\mathrm{OC}_{4} \mathrm{H}_{8}\right)_{2}$ \\
\hline Cryst size, $\mathrm{mm}^{3}$ & $0.148 \times 0.248 \times 0.431$ & $0.138 \times 0.207 \times 0.515$ & $0.108 \times 0.118 \times 0.335$ \\
\hline $\mathrm{Fw}, \mathrm{g} / \mathrm{mol}$ & 1262.66 & 505.68 & 649.89 \\
\hline Space group & $P \overline{1} \quad$ (No. 2) & $\begin{array}{c}\mathrm{P} 2{ }_{1} / \mathrm{n} \text { (No. } 14, \text { non- } \\
\left.\text { standard setting of } \mathrm{P} 2_{1} / \mathrm{c}\right) \text { ) }\end{array}$ & $\begin{array}{c}\text { P } 21 / \text { n (non-standard } \\
\text { setting of P } 21 / c, \text { No. 14) }\end{array}$ \\
\hline$a, \AA$ & $14.5589(8)$ & $10.7463(5)$ & $16.6003(7)$ \\
\hline$b, \AA$ & $14.7207(9)$ & $15.8013(7)$ & $10.2226(5)$ \\
\hline$c, \AA$ & $15.5027(9)$ & $12.5759(5)$ & $17.3738(8)$ \\
\hline$\alpha, \operatorname{deg}$ & $80.529(2)$ & 90 & 90 \\
\hline$\beta, \operatorname{deg}$ & $85.149(2)$ & 103.3951(11) & $94.4356(12)$ \\
\hline$\gamma$, deg & $83.381(2)$ & 90 & 90 \\
\hline$V, \AA$ & $3248.1(3)$ & 2077.36(16) & $2939.5(2)$ \\
\hline Z & 2 & 4 & 4 \\
\hline $\mathrm{T}, \mathrm{K}$ & $100(2)$ & $100(2)$ & $100(2)$ \\
\hline$\rho$ calcd, $\mathrm{g} \mathrm{cm}^{-3}$ & 1.291 & 1.617 & 1.469 \\
\hline Reflns collected/2 $2 \Theta_{\max }$ & $65382 / 55.14$ & $55855 / 70.04$ & $65585 / 60.22$ \\
\hline Unique reflns $/ I>2 \sigma(I)$ & $14938 / 10457$ & $9144 / 7720$ & $8641 / 6690$ \\
\hline No. of params/restraints & $824 / 0$ & $298 / 0$ & $388 / 0$ \\
\hline$\lambda, \AA$ & 0.71073 & 0.71073 & 0.71073 \\
\hline $\mathrm{R} 1^{\mathrm{a}} /$ goodness of $\mathrm{fit}^{\mathrm{b}}$ & $0.0582 / 1.071$ & $0.0292 / 1.077$ & $0.0304 / 1.033$ \\
\hline $\mathrm{wR2}^{\mathrm{c}}(I>2 \sigma(I))$ & 0.1092 & 0.0638 & 0.0622 \\
\hline Residual density, e $\AA^{-3}$ & $+0.914 /-0.762$ & $+0.617 /-0.791$ & $+0.663 /-0.468$ \\
\hline
\end{tabular}




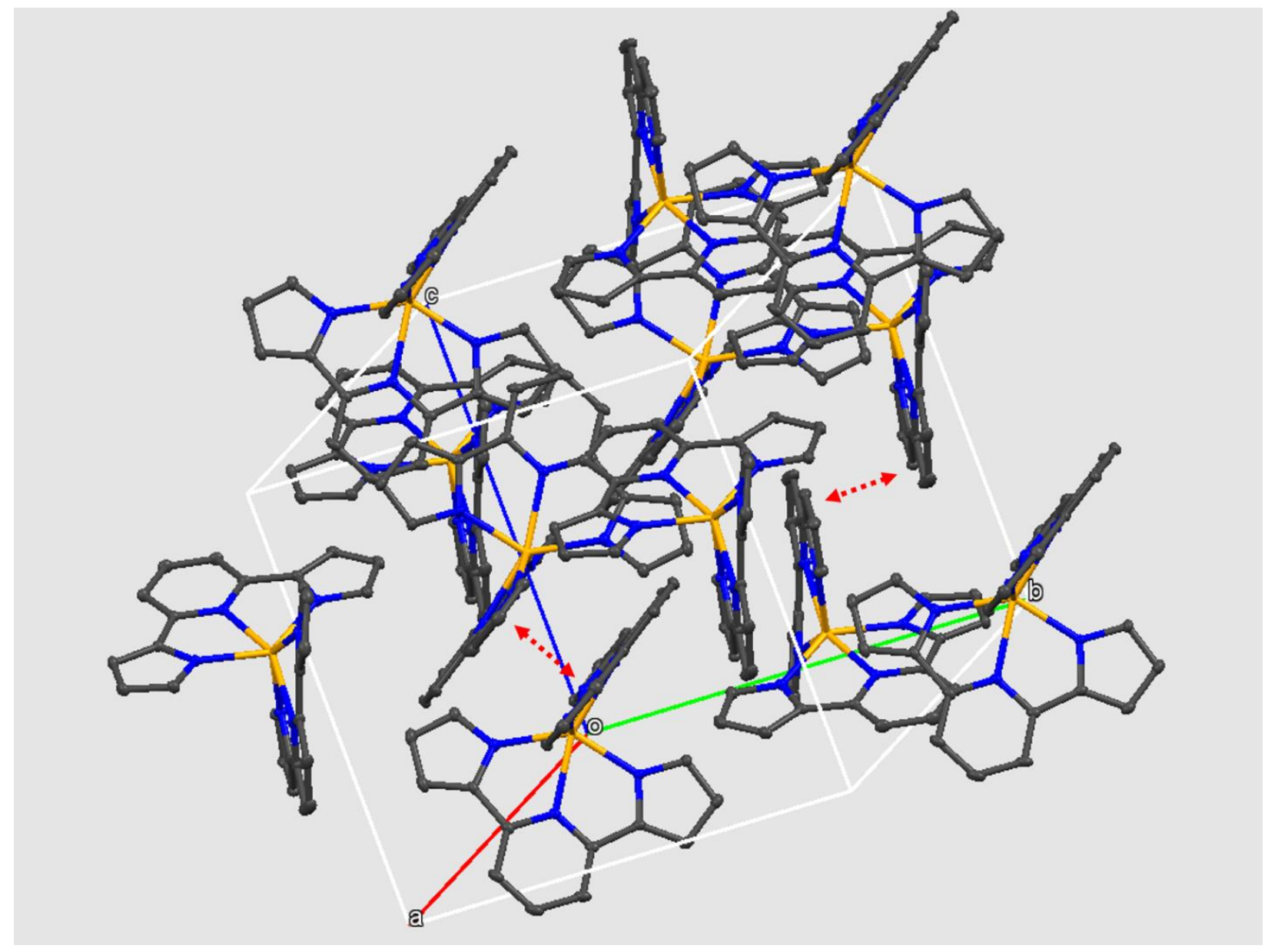

Figure S23. Representation of the crystal packing in the solid-state structure of $\mathrm{Zr}\left({ }^{\mathrm{H} P D P}{ }^{\mathrm{H}}\right)_{2}$. The outline shows the shape of the unit cell. Hydrogen atoms are omitted for clarity. 


\section{Absorption and Emission Spectra}

Due to the limited solubility of several $\operatorname{Zr}(\mathrm{PDP})_{2}$ derivatives in benzene, an accurate determination of the concentration was not feasible in all cases. Therefore, spectra recorded in benzene are provided in units of absorbance. Molar absorptivity values, $\varepsilon_{\lambda}$, are reported for spectra recorded in THF solutions. For all complexes, the overall shape of the absorption and emission spectra is almost completely unaffected by the change in solvent. However, due to the high moisturesensitivity of the complexes, with the exception of $\mathrm{Zr}\left({ }^{\mathrm{Mes} P D P}{ }^{\mathrm{Ph}}\right)_{2}$, the provided molar absorptivity should be taken with a grain of salt. Despite our best efforts at drying solvent, glassware, and quartz cuvettes, partial decomposition may have occurred given the very low concentrations required to obtain optically dilute solutions.
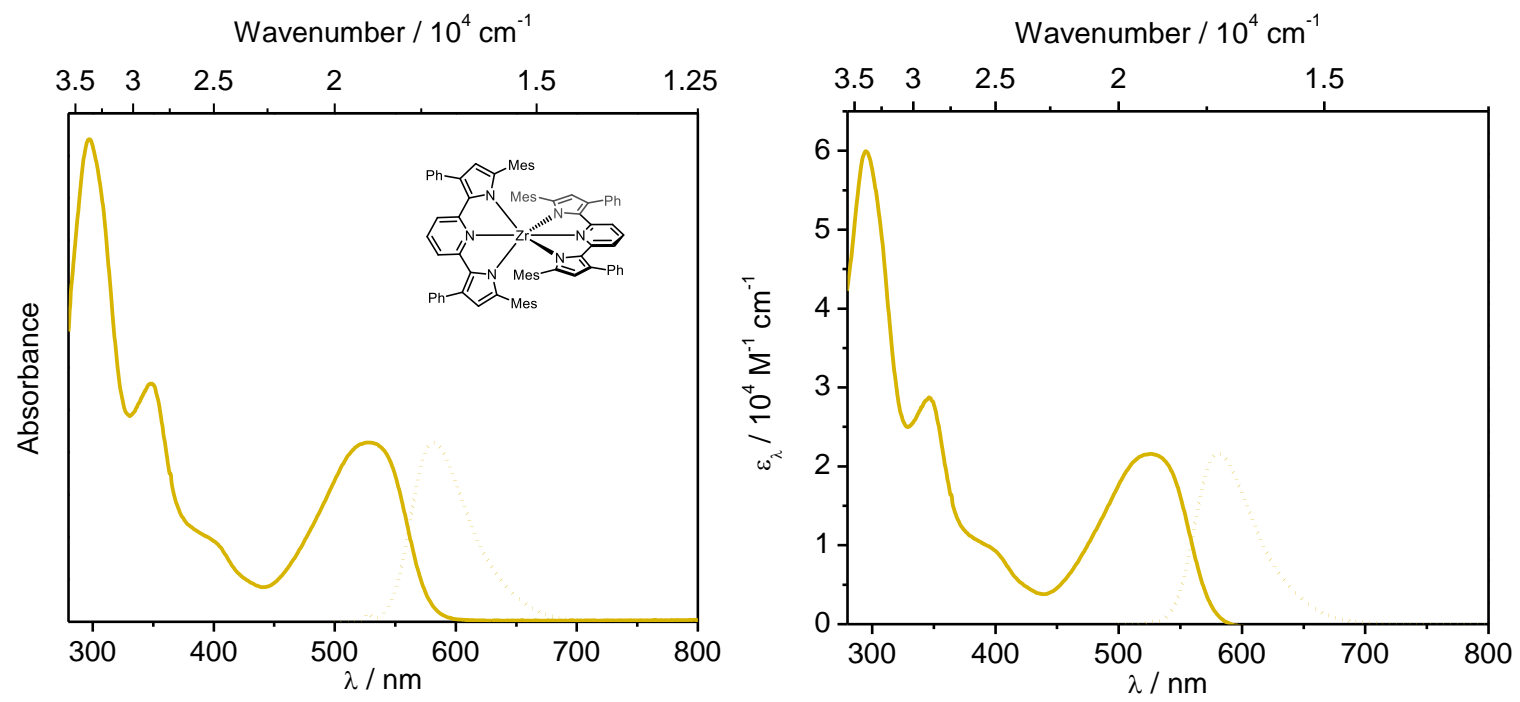

Figure S 24. Absorption (solid lines) and emission spectra (dotted lines) of $\mathrm{Zr}\left({ }^{\text {Mes }}{ }^{P D P}{ }^{P h}\right)_{2}$ in $\mathrm{C}_{6} \mathrm{H}_{6}$ (left) and THF (right) solution at room temperature. 

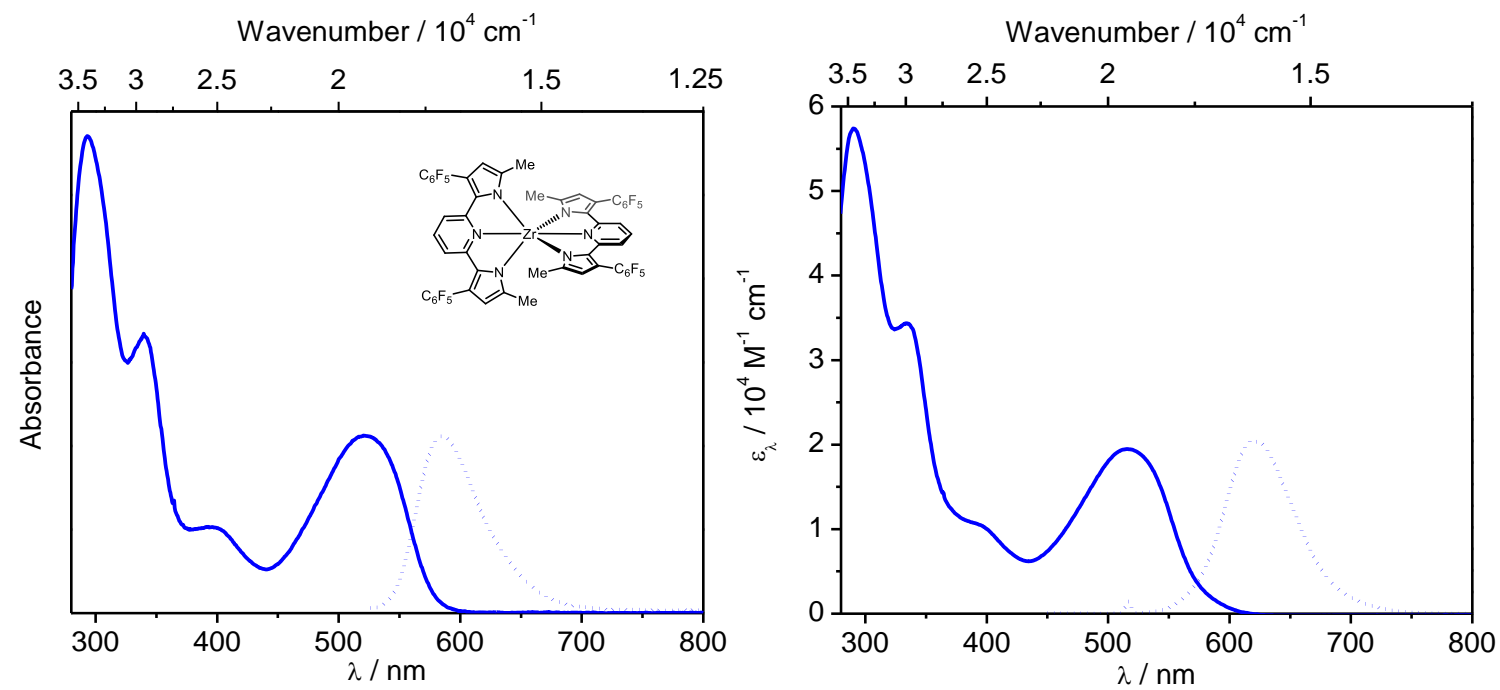

Figure S25. Absorption (solid lines) and emission spectra (dotted lines) of $\mathrm{Zr}\left({ }^{\text {MePDP }}{ }^{\mathrm{C6F5}}\right)_{2}$ in $\mathrm{C}_{6} \mathrm{H}_{6}$ (left) and THF (right) solution at room temperature.

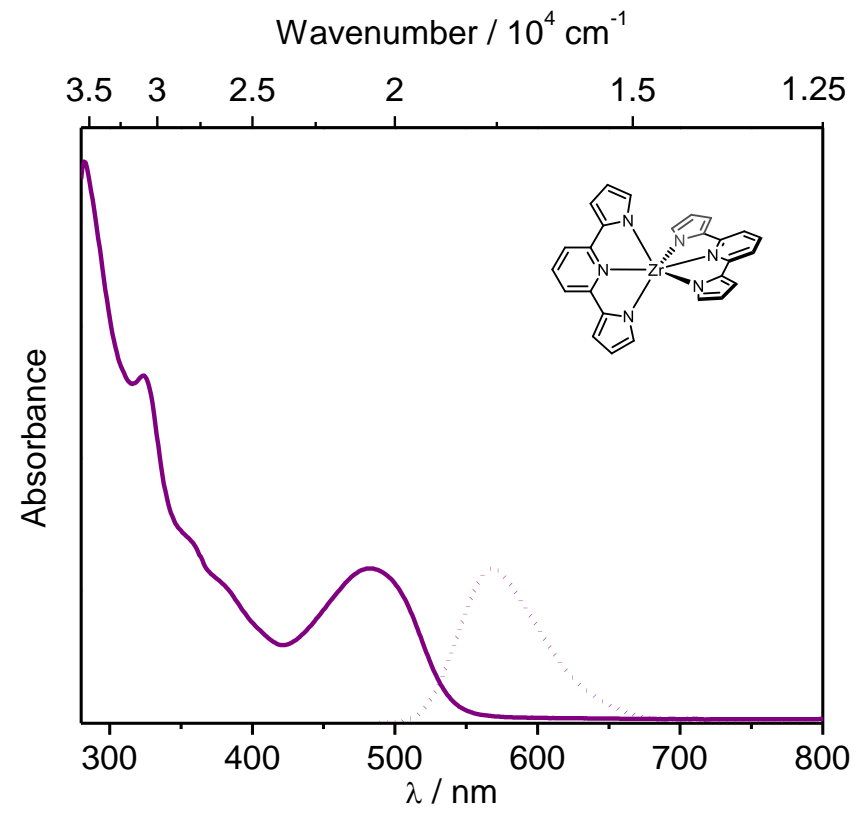

Figure S26. Absorption (solid lines) and emission spectra (dotted lines) of $\mathrm{Zr}\left({ }^{\mathrm{H} P D P}{ }^{\mathrm{H}}\right)_{2}$ in $\mathrm{C}_{6} \mathrm{H}_{6}$ solution at room temperature. 

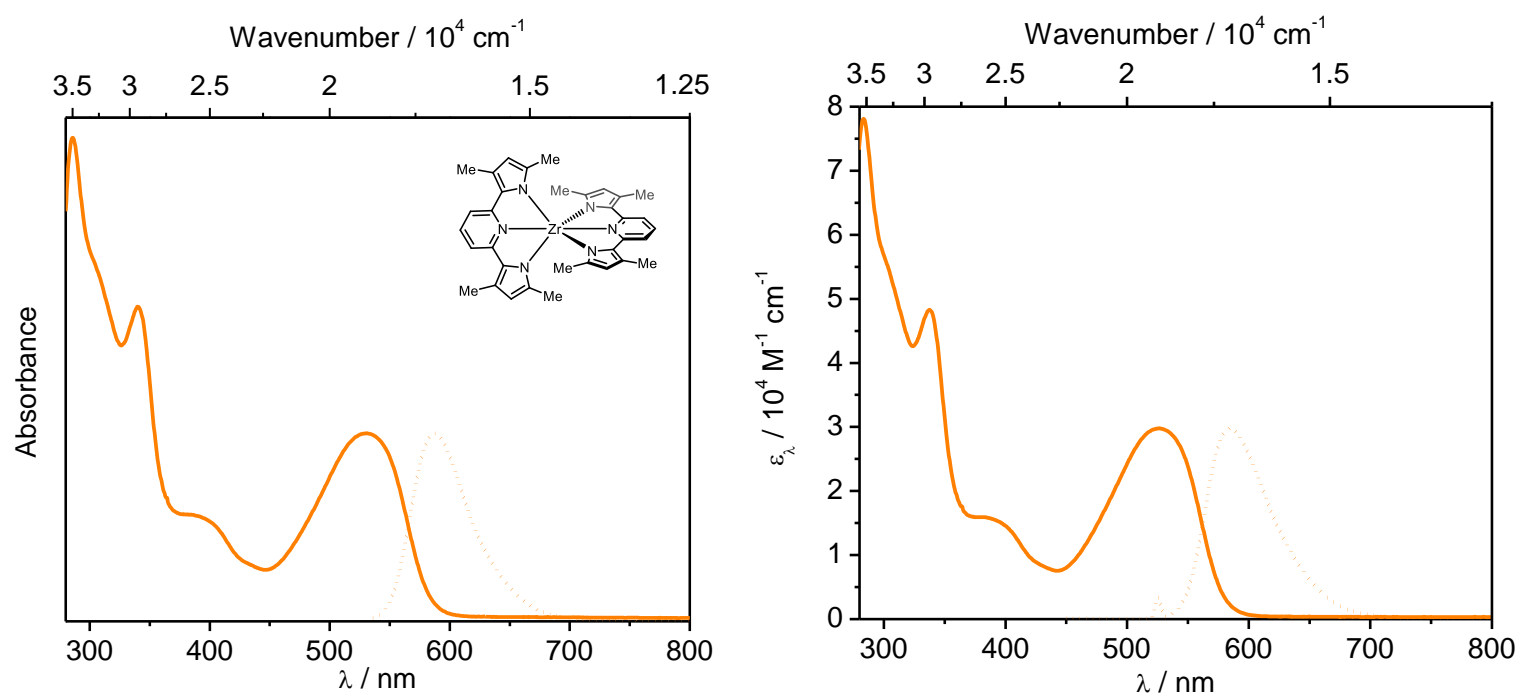

Figure S27. Absorption (solid lines) and emission spectra (dotted lines) of $\mathrm{Zr}\left({ }^{\mathrm{MePDPMe}}\right)_{2}$ in $\mathrm{C}_{6} \mathrm{H}_{6}$ (left) and THF (right) solution at room temperature.
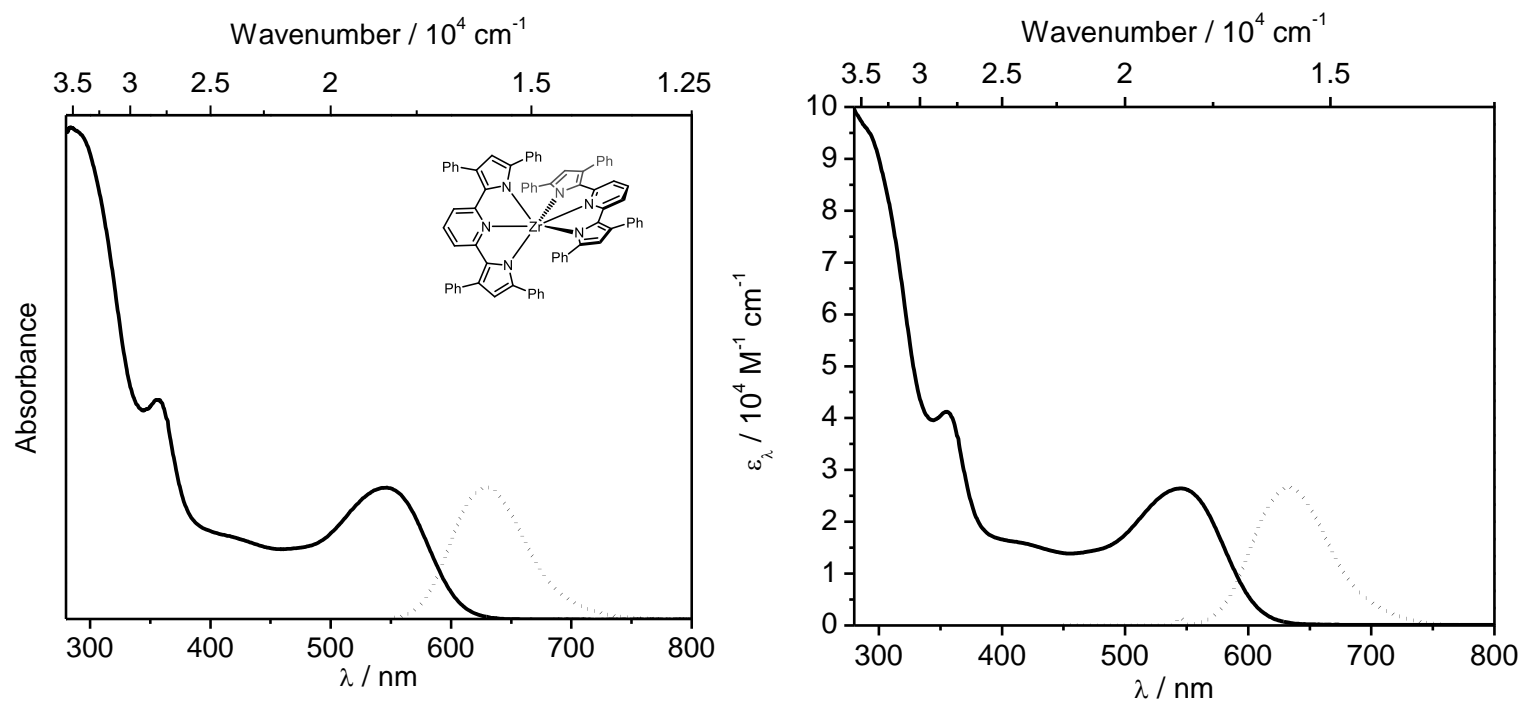

Figure S28. Absorption (solid lines) and emission spectra (dotted lines) of $\mathrm{Zr}\left({ }^{\mathrm{Ph} P D P}{ }^{\mathrm{Ph}}\right)_{2}$ in $\mathrm{C}_{6} \mathrm{H}_{6}$ (left) and THF (right) solution at room temperature. 

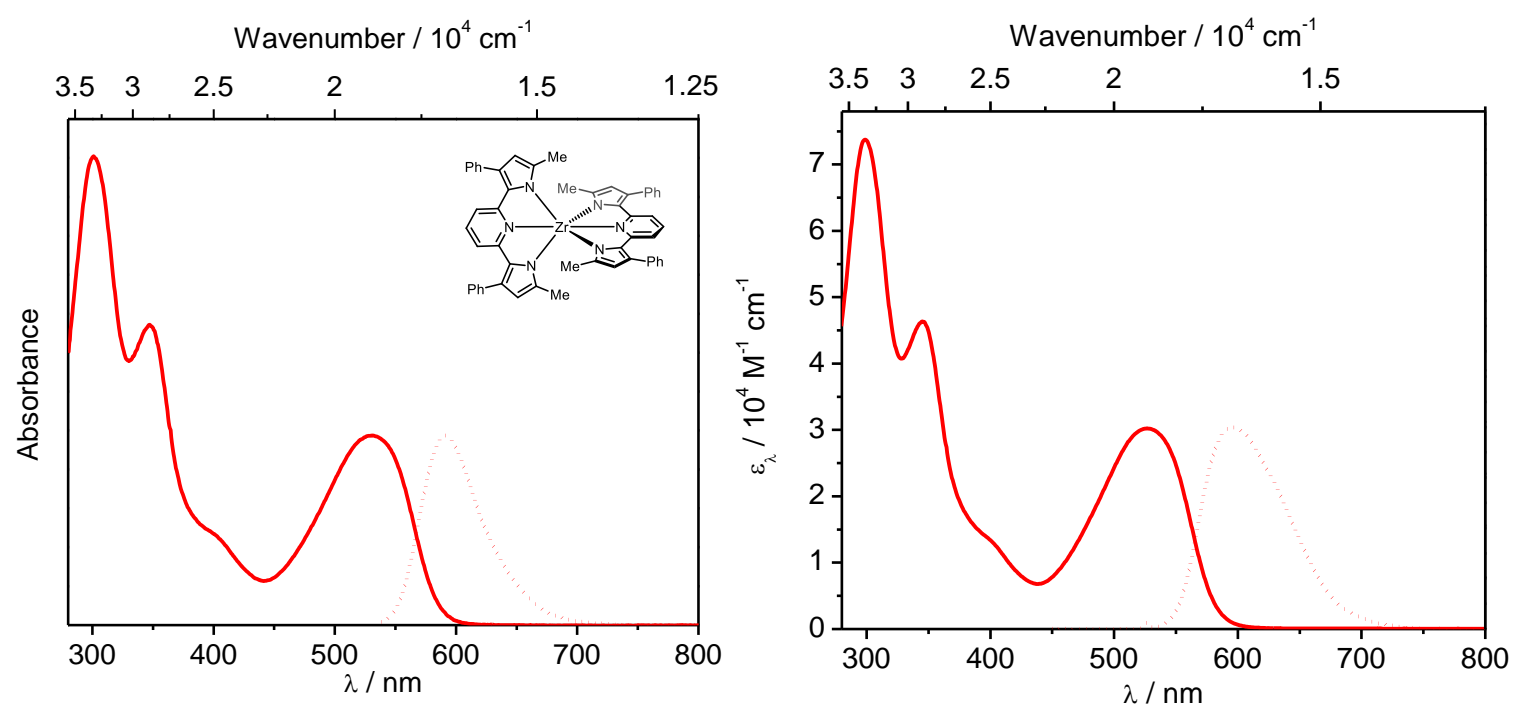

Figure S29. Absorption (solid lines) and emission spectra (dotted lines) of $\mathrm{Zr}\left({ }^{\mathrm{MePDP}}{ }^{\mathrm{Ph}}\right)_{2}$ in $\mathrm{C}_{6} \mathrm{H}_{6}$ (left) and THF (right) solution at room temperature.
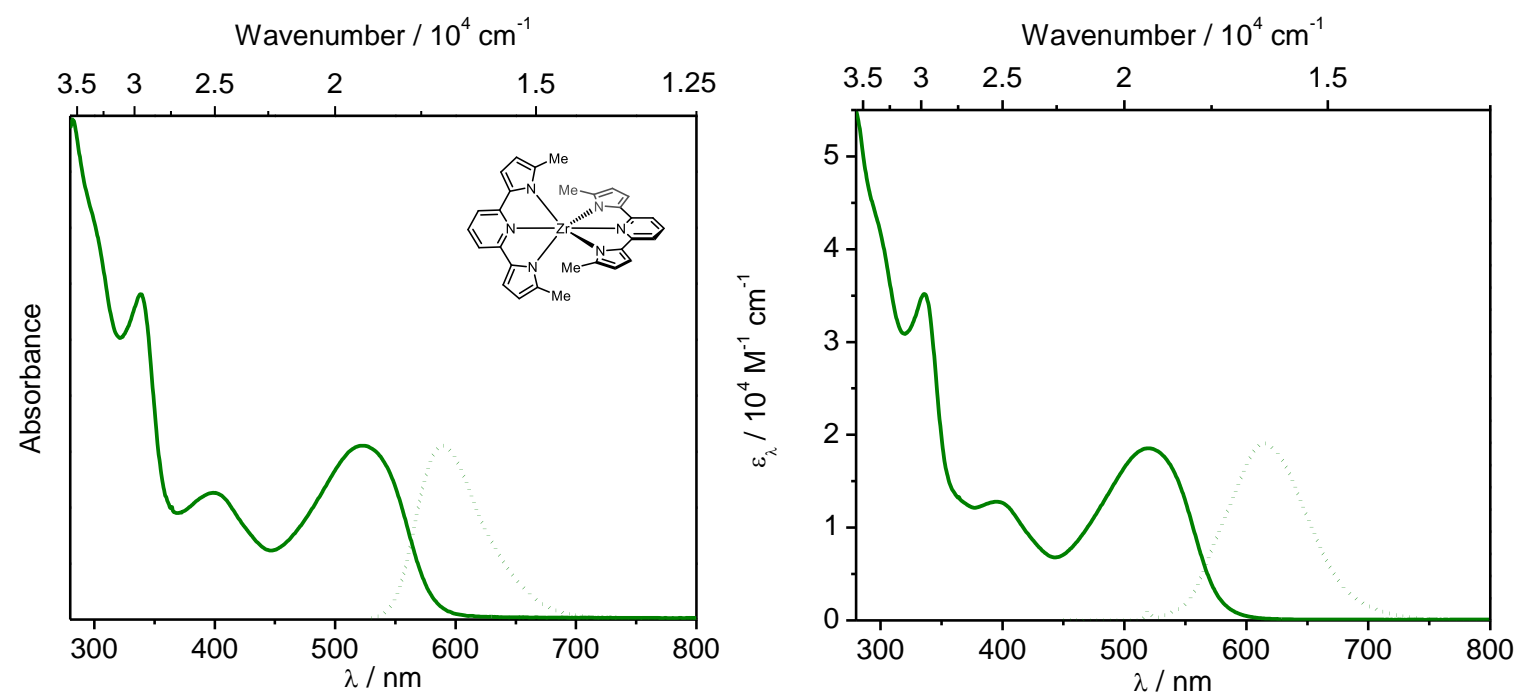

Figure S30. Absorption (solid lines) and emission spectra (dotted lines) of $\mathrm{Zr}\left({ }^{\left({ }^{e P D P H}\right.}\right)_{2}$ in $\mathrm{C}_{6} \mathrm{H}_{6}$ (left) and THF (right) solution at room temperature. 


\section{Quantum Yield Determination}

The quantum yield of $\mathrm{Zr}\left({ }^{\mathrm{R} 1} \mathrm{PDP}^{\mathrm{R} 2}\right)_{2}$ were determined via comparative method. ${ }^{3,4}$ Rhodamine $6 \mathrm{G}$ in ethanol $(\Phi=0.94)$ was used as a standard. For $\mathrm{Zr}\left({ }^{\left({ }^{2} P D P H\right.}\right)_{2}$ in $\mathrm{THF}$, Coumarin153 in ethanol $(\Phi=$ 0.38) was used. The quantum yield was calculated by using the following equation:

$$
\Phi_{\mathrm{X}}=\Phi_{\mathrm{ST}}\left(\frac{\operatorname{Grad}_{\mathrm{X}}}{\operatorname{Grad}_{\mathrm{ST}}}\right)\left(\frac{\mathrm{n}_{\mathrm{X}}^{2}}{\mathrm{n}_{\mathrm{ST}}^{2}}\right)
$$

The subscripts $X$ and ST stand for the sample and the standard, respectively. $\Phi$ is the photoluminescence quantum yield. Grad is the gradient from the plot of integrated photoluminescence intensity versus absorbance, and $\mathrm{n}$ is the refractive index of the solvent.

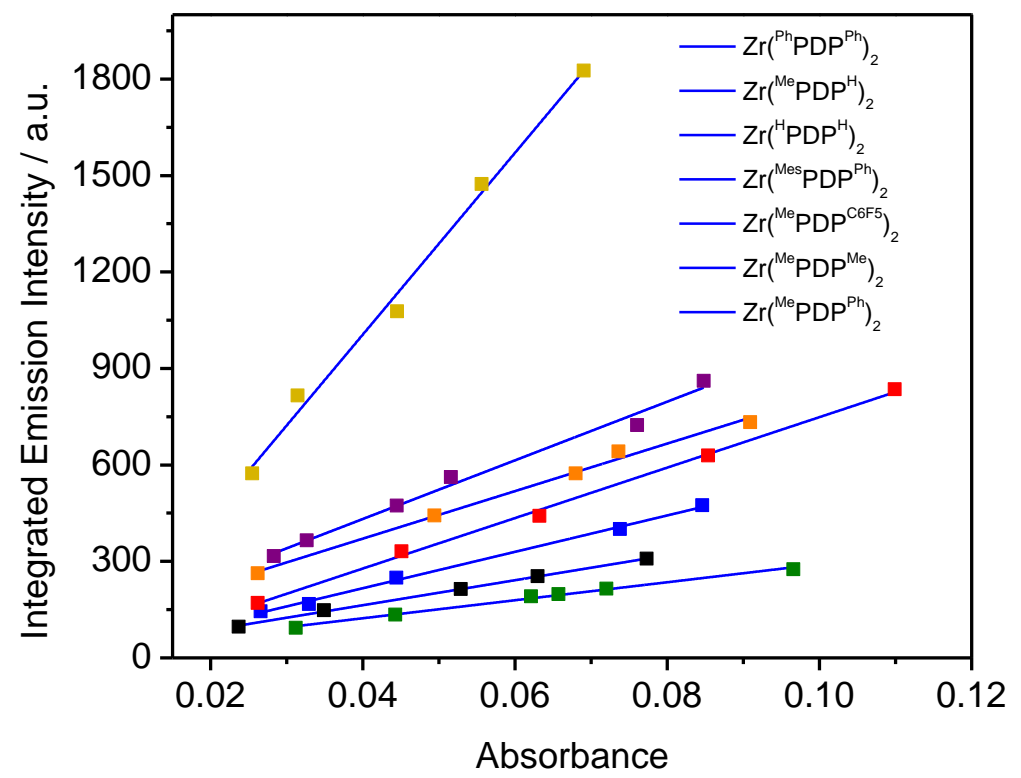

Figure S31. Plot of absorbance at $488 \mathrm{~nm}$ (for $\mathrm{Zr}\left({ }^{\mathrm{H} P D P}{ }^{\mathrm{H}}\right)_{2}$ in THF, absorbance at $421 \mathrm{~nm}$ was recorded) versus integration of the emission spectrum for $\mathrm{Zr}\left({ }^{\mathrm{R} 1} \mathrm{PDP}^{\mathrm{R} 2}\right)_{2}$ in THF. The blue lines represent linear fits of the data. 


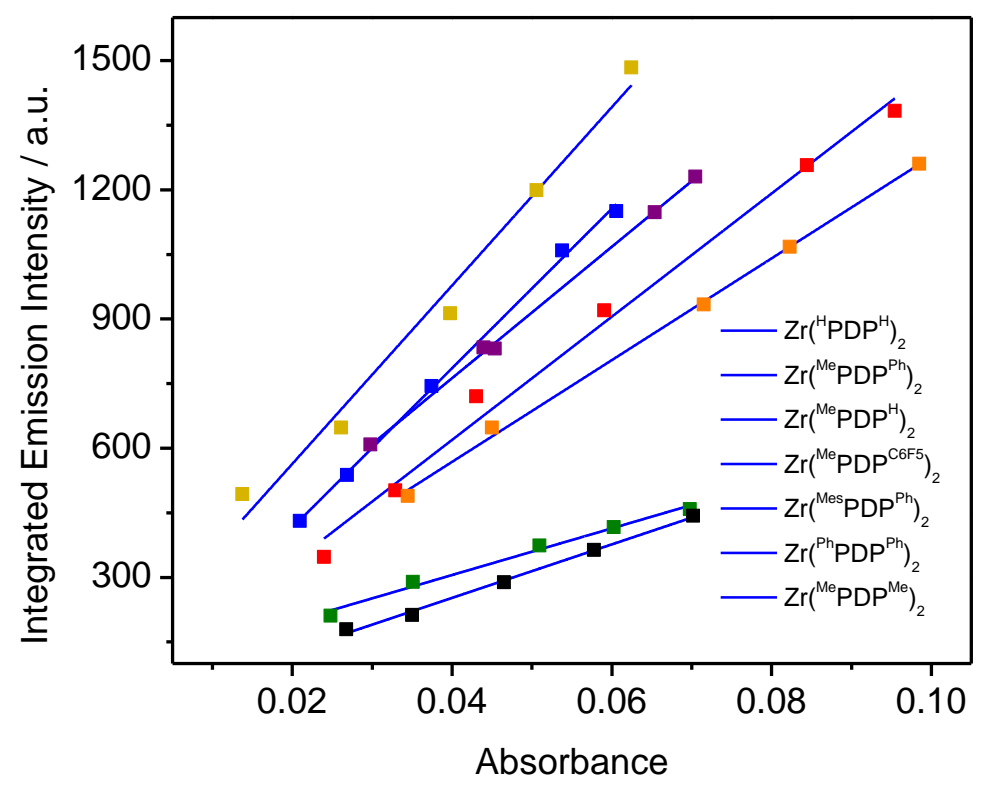

Figure S32. Plot of absorbance at $488 \mathrm{~nm}$ versus integration of the emission spectrum for $\mathrm{Zr}\left({ }^{\mathrm{R} 1} \mathrm{PDP}{ }^{\mathrm{R} 2}\right)_{2}$ in $\mathrm{C}_{6} \mathrm{H}_{6}$. The blue lines represent linear fits of the data.

Table S3. Gradients used for the quantum yield determinations.

\begin{tabular}{|c|c|c|c|c|}
\hline & Gradient / THF & $\Phi /$ THF & Gradient / $\mathrm{C}_{6} \mathrm{H}_{6}$ & $\Phi / \mathrm{C}_{6} \mathrm{H}_{6}$ \\
\hline $\mathrm{Zr}\left({ }^{\mathrm{MePDP}} \mathrm{PGF5}^{\mathrm{C}}\right)_{2}$ & 5657 & 0.09 & 18514 & 0.34 \\
\hline $\mathrm{Zr}\left(\mathrm{MePDP}^{\mathrm{Ph}}\right)_{2}$ & 7847 & 0.12 & 14304 & 0.27 \\
\hline $\mathrm{Zr}\left({ }^{\mathrm{Me}} \mathrm{PDP} \mathrm{P}^{\mathrm{H}}\right)_{2}$ & 2800 & 0.05 & 5419 & 0.10 \\
\hline $\mathrm{Zr}\left(\mathrm{MePDPMe}_{2}\right.$ & 7390 & 0.14 & 11815 & 0.22 \\
\hline $\mathrm{Zr}\left({ }^{\mathrm{H}} \mathrm{PDP}^{\mathrm{H}}\right)_{2}$ & 9120 & 0.13 & 15245 & 0.28 \\
\hline $\mathrm{Zr}\left({ }^{\left(\mathrm{Ph} P D P^{\mathrm{Ph}}\right.}\right)_{2}$ & 3887 & 0.06 & 6212 & 0.11 \\
\hline $\mathrm{Zr}\left({ }^{\text {Mes }} \mathrm{PDP}^{\mathrm{Ph}}\right)_{2}$ & $28260^{b}$ & $0.45^{b}$ & $20708^{b}$ & $0.38^{b}$ \\
\hline
\end{tabular}

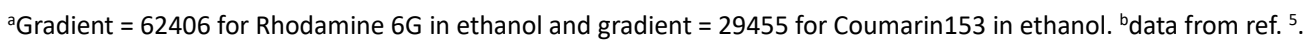




\section{Fits of Time-Resolved Emission Data}

Fits of the data obtained via time-resolved emission spectroscopy were performed using the following protocol. The counts of the data points prior to excitation were used to evaluate the background noise of the experiment and their average value was substracted from the raw data as a baseline correction. The resulting data was fit using a single exponential decay:

$$
I(t)=I_{0} \cdot e^{-\frac{t}{\tau_{0}}}
$$
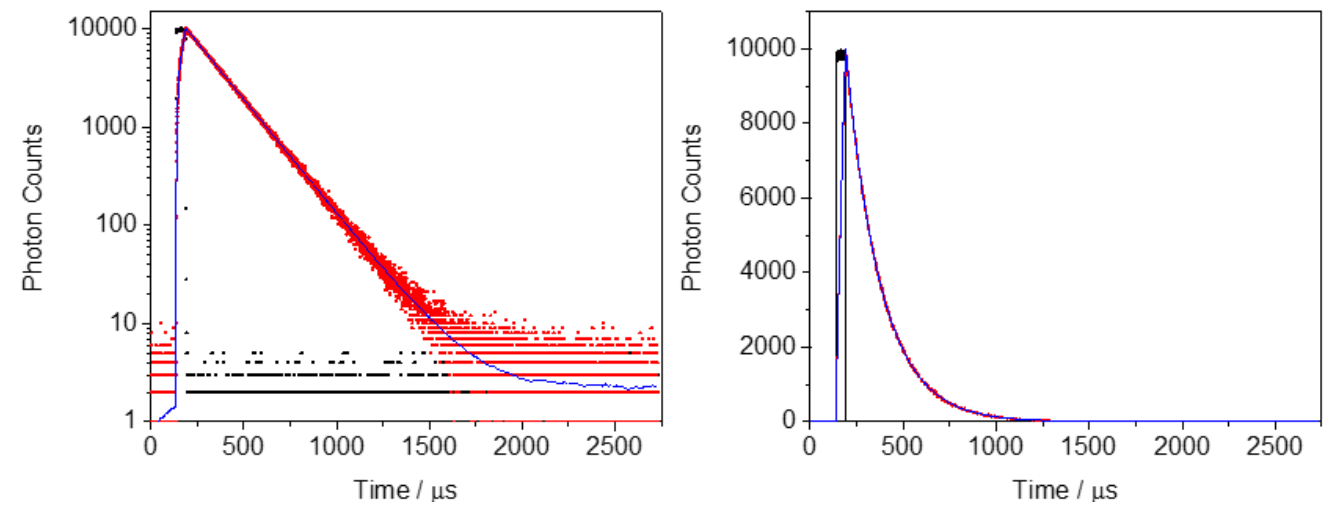

Figure S33. Representative example for time-resolved emission data for $\mathrm{Zr}\left({ }^{\mathrm{Ph} P D P}{ }^{\mathrm{Ph}}\right)_{2}$ in $\mathrm{C}_{6} \mathrm{H}_{6}$ at room temperature (red) detected at $\lambda_{\text {em max }}$ upon excitation at $516 \mathrm{~nm}$. The navy line shows the fit to a singleexponential decay with $\tau_{0}=190 \mu \mathrm{s}$ and the black trace shows the excitation pulse.
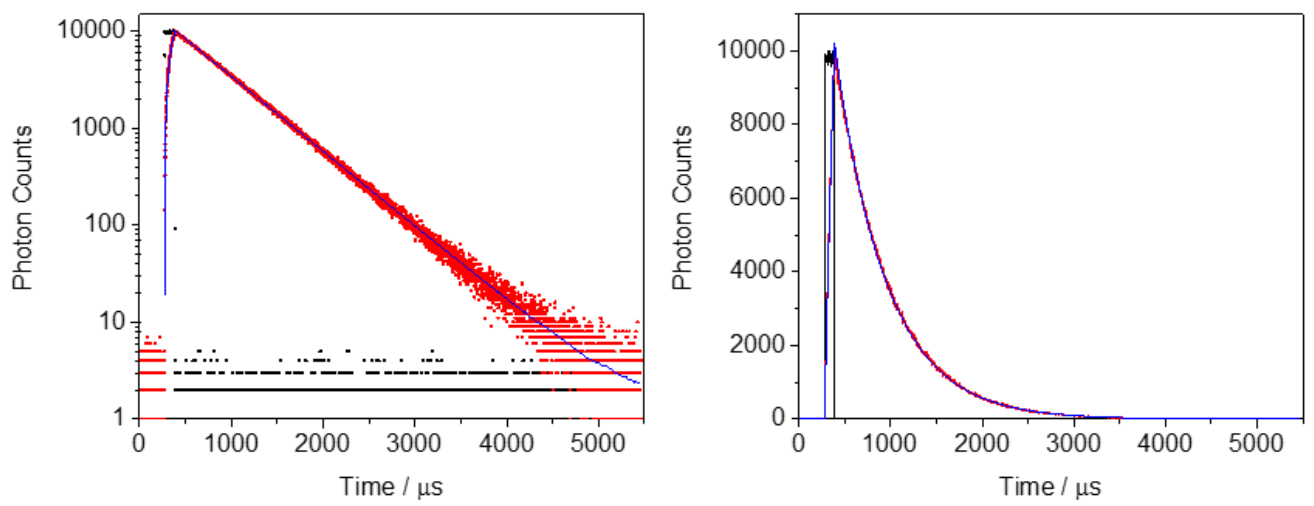

Figure S34. Representative example for time-resolved emission data for $\mathrm{Zr}\left({ }^{\mathrm{MePDPMe}}\right)_{2}$ in $\mathrm{C}_{6} \mathrm{H}_{6}$ at room temperature (red) detected at $\lambda_{\mathrm{em} \max }$ upon excitation at $516 \mathrm{~nm}$. The navy line shows the fit to a singleexponential decay with $\tau_{0}=576 \mu \mathrm{s}$ and the black trace shows the excitation pulse. 

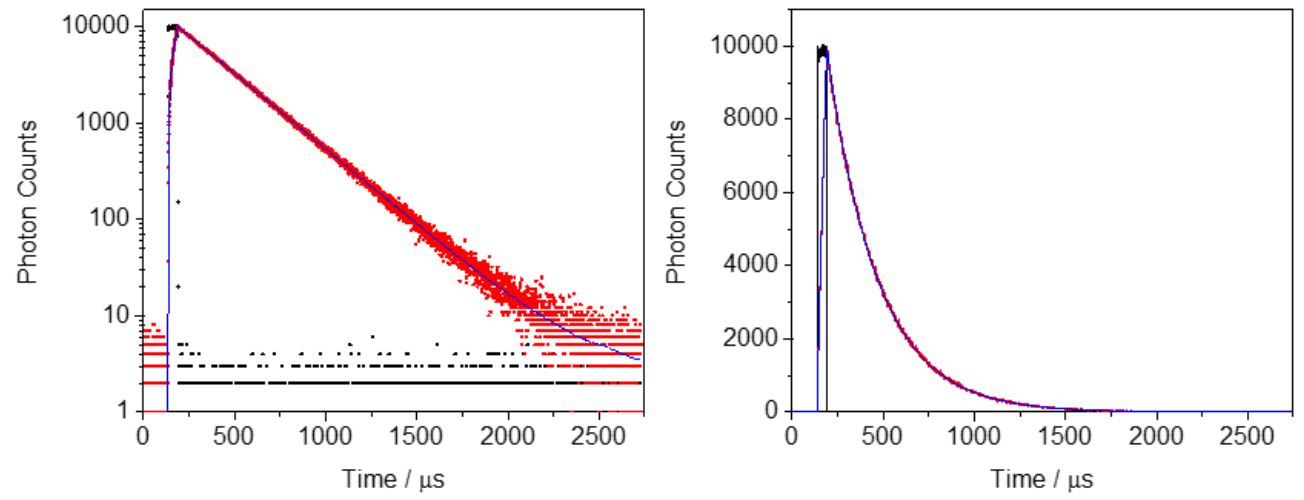

Figure S35. Representative example for time-resolved emission data for $\mathrm{Zr}\left({ }^{\mathrm{Me}} \mathrm{PDP}^{\mathrm{H}}\right)_{2}$ in $\mathrm{C}_{6} \mathrm{H}_{6}$ at room temperature (red) detected at $\lambda_{\mathrm{em} \text { max }}$ upon excitation at $516 \mathrm{~nm}$. The navy line shows the fit to a singleexponential decay with $\tau_{0}=260 \mu \mathrm{s}$ and the black trace shows the excitation pulse.
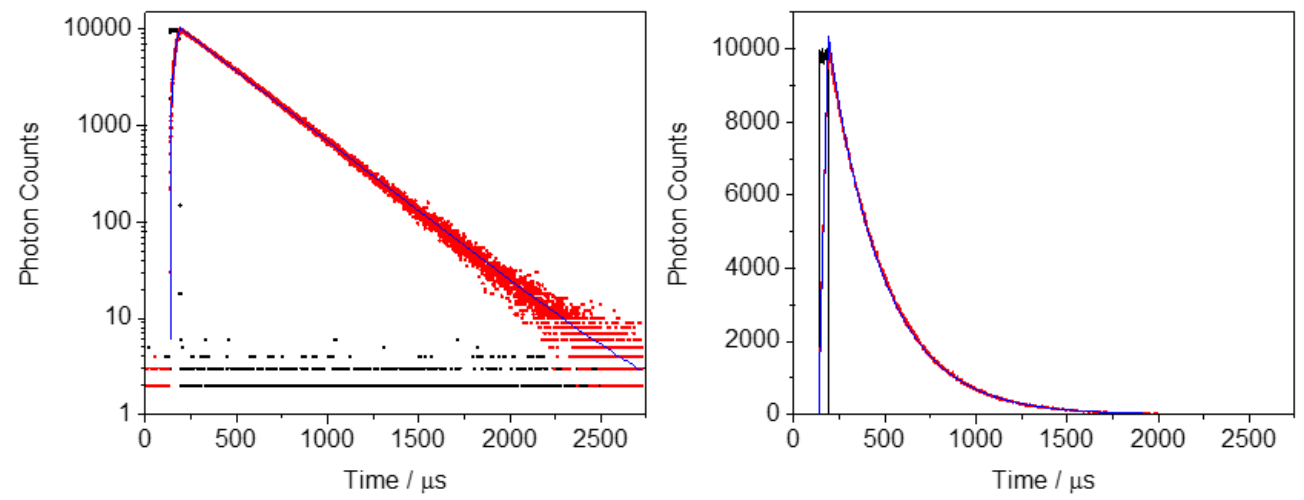

Figure S36. Representative example for time-resolved emission data for $\mathrm{Zr}\left({ }^{\text {MePDP }}{ }^{\mathrm{C6F5}}\right)_{2}$ in $\mathrm{C}_{6} \mathrm{H}_{6}$ at room temperature (red) detected at $\lambda_{\mathrm{em} \max }$ upon excitation at $516 \mathrm{~nm}$. The navy line shows the fit to a singleexponential decay with $\tau_{0}=313 \mu \mathrm{s}$ and the black trace shows the excitation pulse.
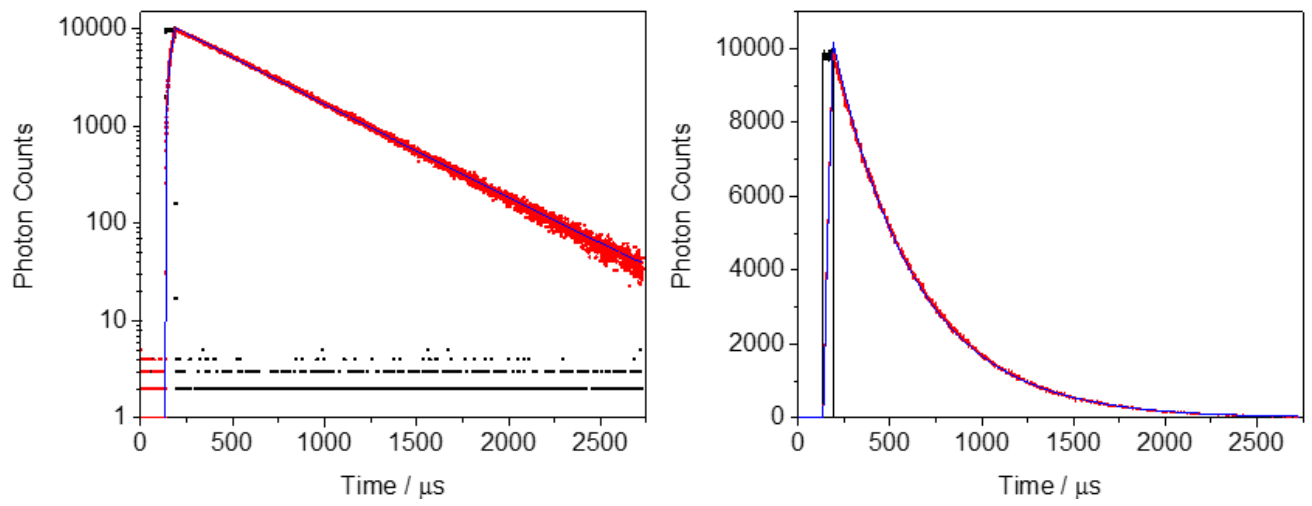

Figure S37. Representative example for time-resolved emission data for $\mathrm{Zr}\left({ }^{\mathrm{MePDP}}{ }^{\mathrm{Ph}}\right)_{2}$ in $\mathrm{C}_{6} \mathrm{H}_{6}$ at room temperature (red) detected at $\lambda_{\mathrm{em} \text { max }}$ upon excitation at $516 \mathrm{~nm}$. The navy line shows the fit to a singleexponential decay with $\tau_{0}=474 \mu \mathrm{s}$ and the black trace shows the excitation pulse. 

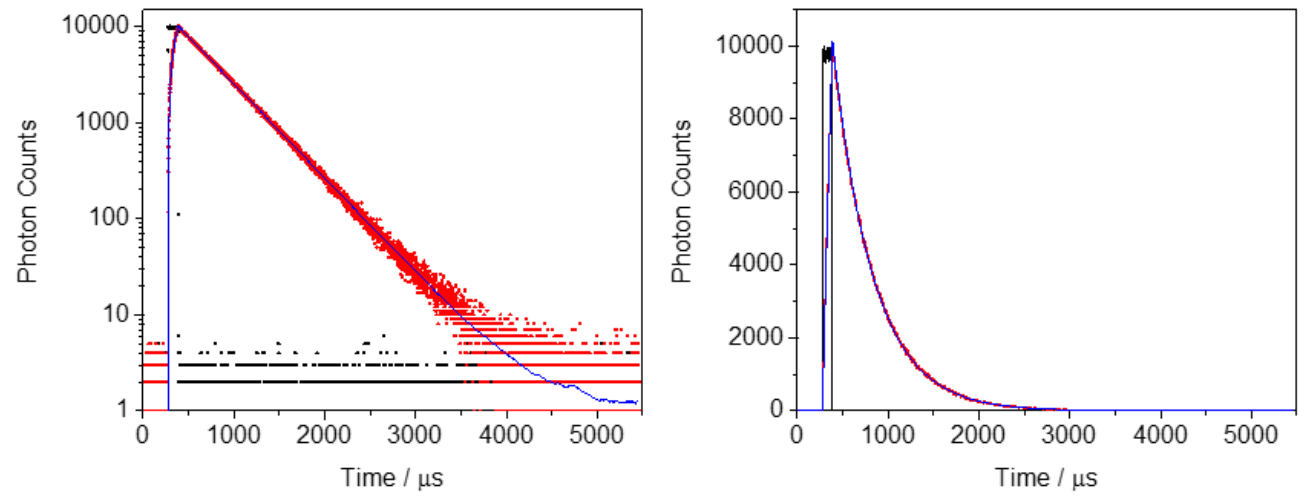

Figure S38. Representative example for time-resolved emission data for $\mathrm{Zr}\left({ }^{\mathrm{H} P D P}{ }^{\mathrm{H}}\right)_{2}$ in $\mathrm{C}_{6} \mathrm{H}_{6}$ at room temperature (red) detected at $\lambda_{\mathrm{em} \text { max }}$ upon excitation at $516 \mathrm{~nm}$. The navy line shows the fit to a singleexponential decay with $\tau_{0}=413 \mu \mathrm{s}$ and the black trace shows the excitation pulse.
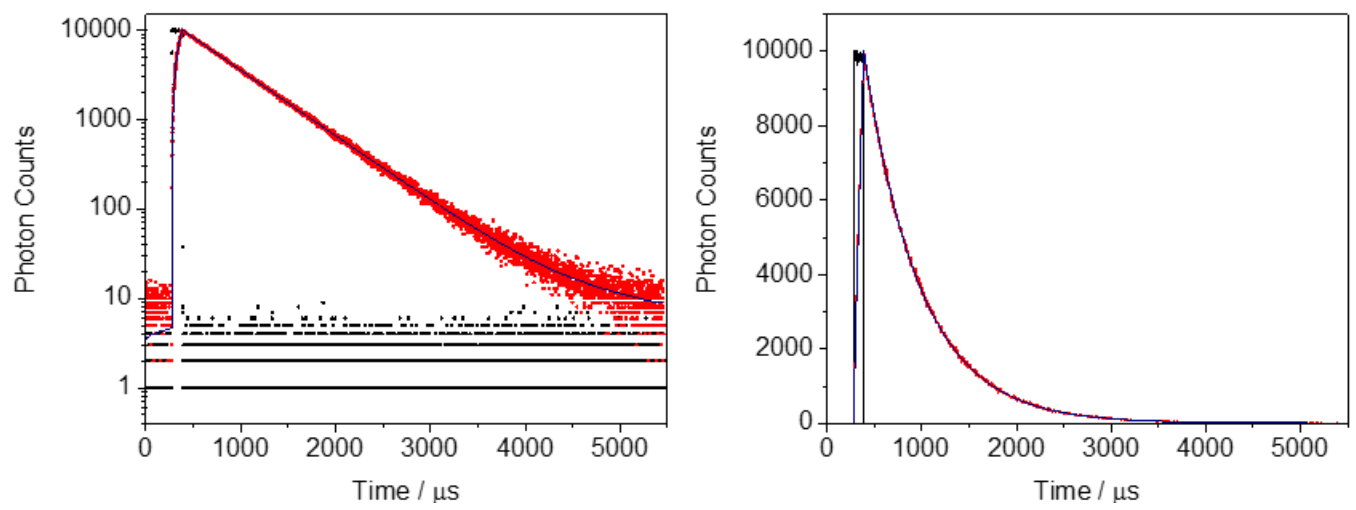

Figure S39. Representative example for time-resolved emission data for $\mathrm{Zr}\left({ }^{\mathrm{HPDPH}}\right)_{2}(\text { thf })_{2}$ in $\mathrm{THF}$ at room temperature (red) detected at $\lambda_{\mathrm{em} \text { max }}$ upon excitation at $456 \mathrm{~nm}$. The navy line shows the fit to a singleexponential decay with $\tau_{0}=609 \mu \mathrm{s}$ and the black trace shows the excitation pulse. 


\section{Cyclic Voltammetry Data}

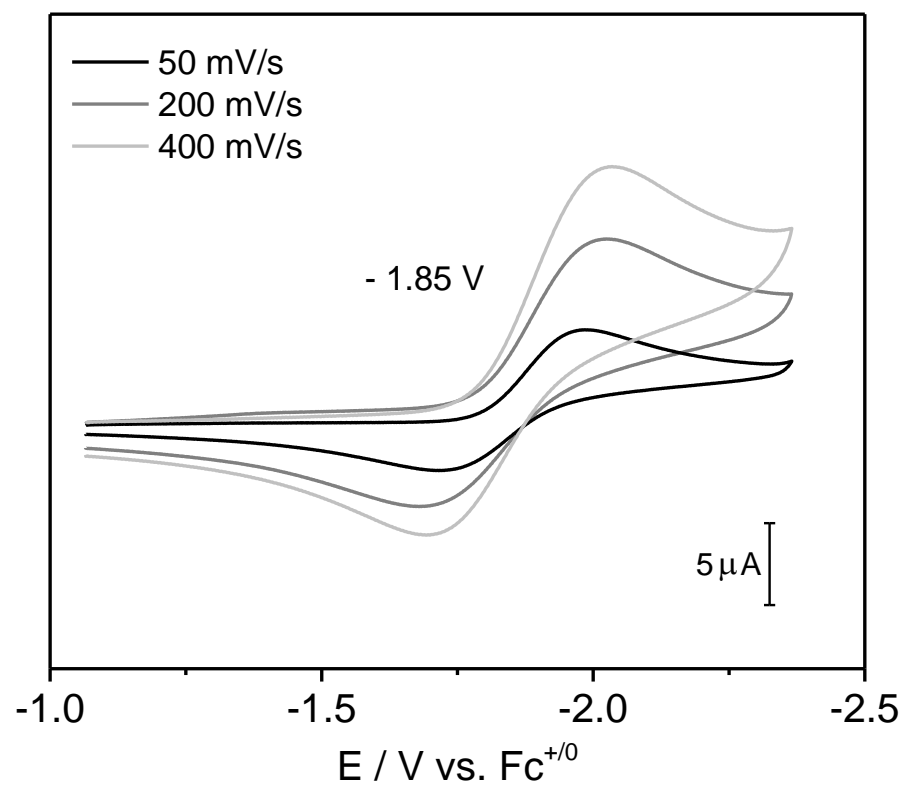

Figure S40. Cyclic voltammogram of $\mathrm{Zr}\left({ }^{\mathrm{Me}} \mathrm{PDP}^{\mathrm{C} 6 F 5}\right)_{2}$ in THF at different scan rates.

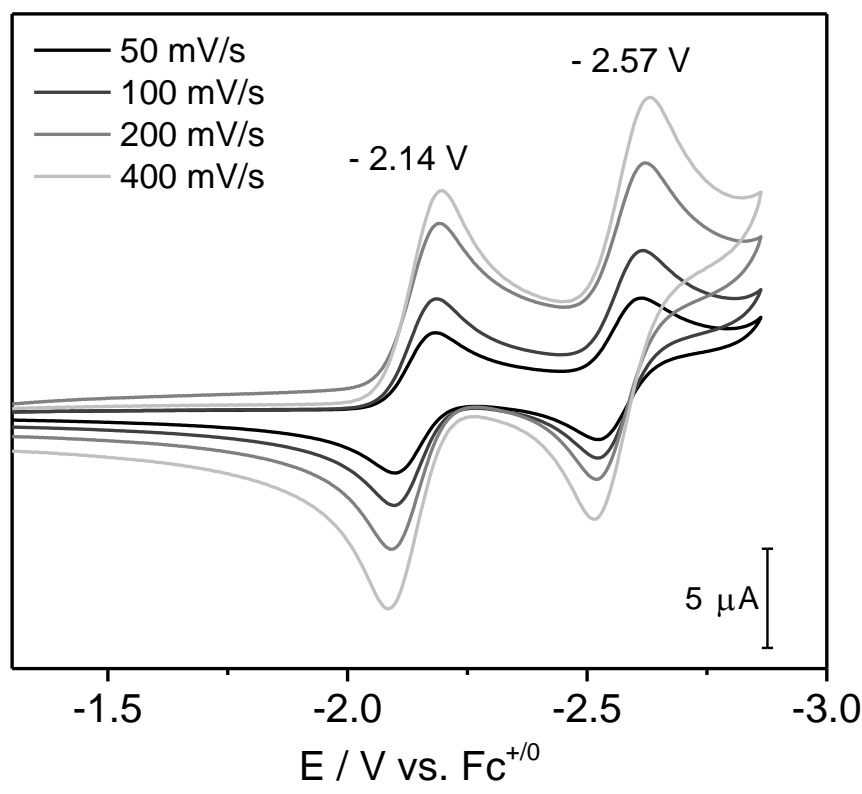

Figure S41. Cyclic voltammogram of $\mathrm{Zr}\left({ }^{\mathrm{Me} P D P}{ }^{\mathrm{Ph}}\right)_{2}$ in 1,2-difluorobenzene at different scan rates. 


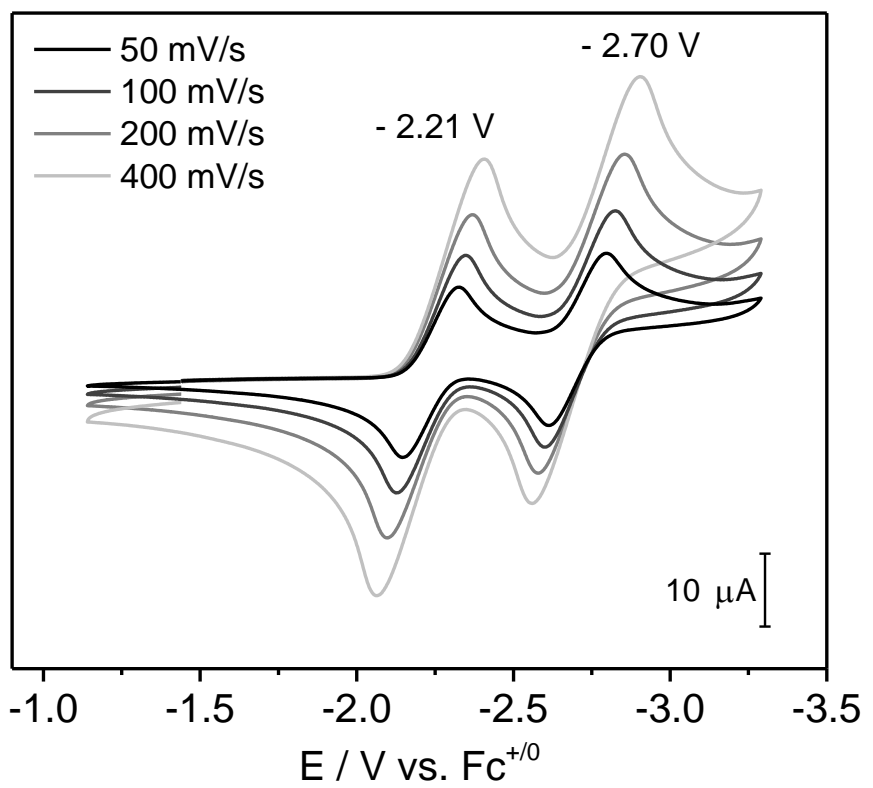

Figure S42. Cyclic voltammogram of Zr(MePDP)2 in THF at different scan rates.

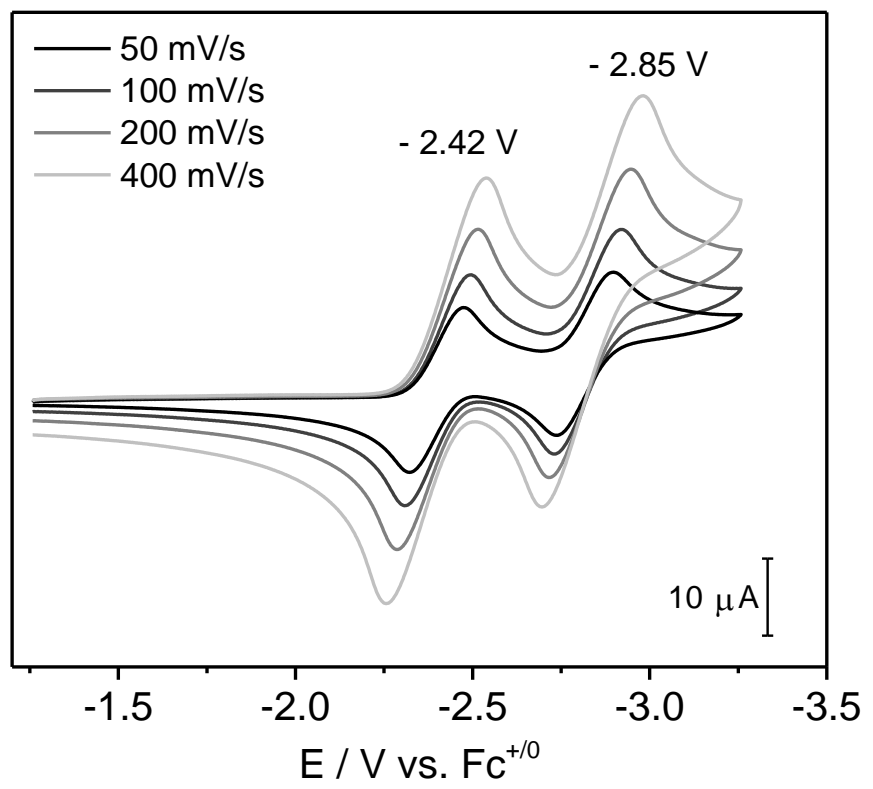

Figure S43. Cyclic voltammogram of $\mathrm{Zr}\left({ }^{\mathrm{Me}} \mathrm{PDP}^{\mathrm{Me}}\right)_{2}$ in THF at different scan rates. 


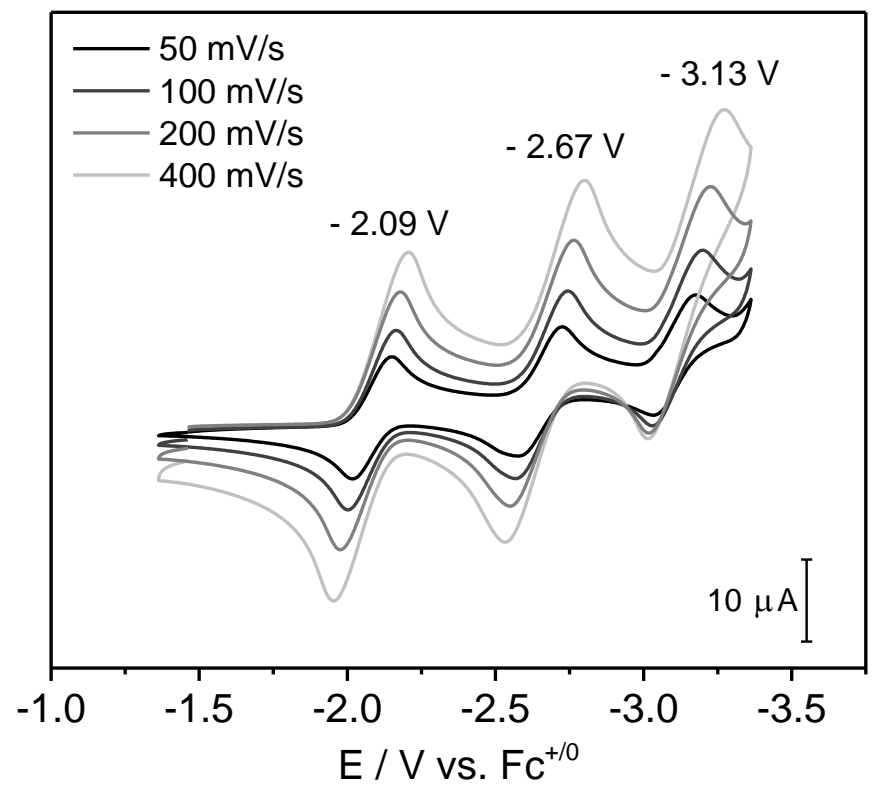

Figure S44. Cyclic voltammogram of $\mathrm{Zr}\left({ }^{\left({ }^{\mathrm{Ph}} \mathrm{PDP}\right.}{ }^{\mathrm{Ph}}\right)_{2}$ in THF at different scan rates.

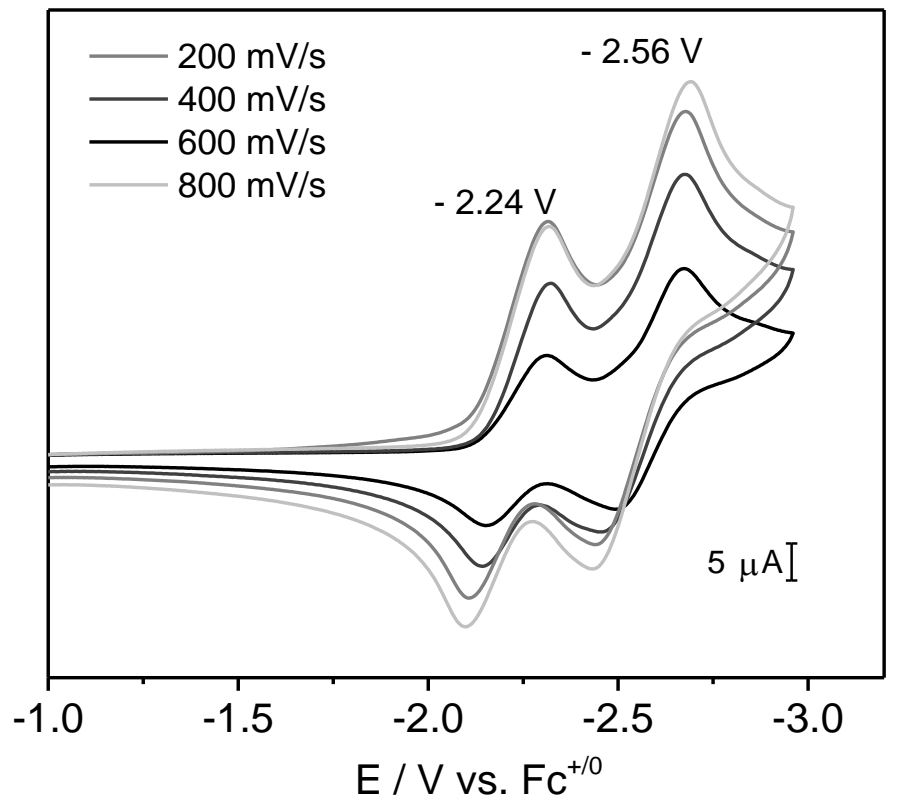

Figure S45. Cyclic voltammogram of $\mathrm{Zr}\left({ }^{\mathrm{H}} \mathrm{PDP}{ }^{\mathrm{H}}\right)_{2}$ in 1,2-difluorobenzene at different scan rates. 


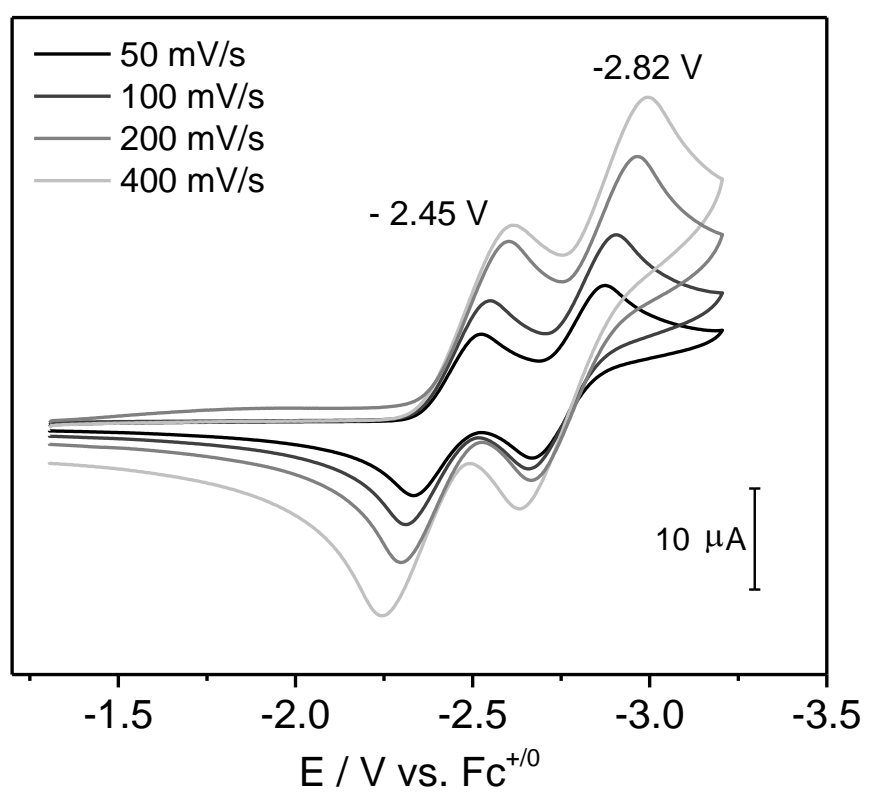

Figure S46. Cyclic voltammogram of $\mathrm{Zr}\left({ }^{\mathrm{H} P D P}{ }^{\mathrm{H}}\right)_{2}(\text { thf })_{2}$ in THF at different scan rates.

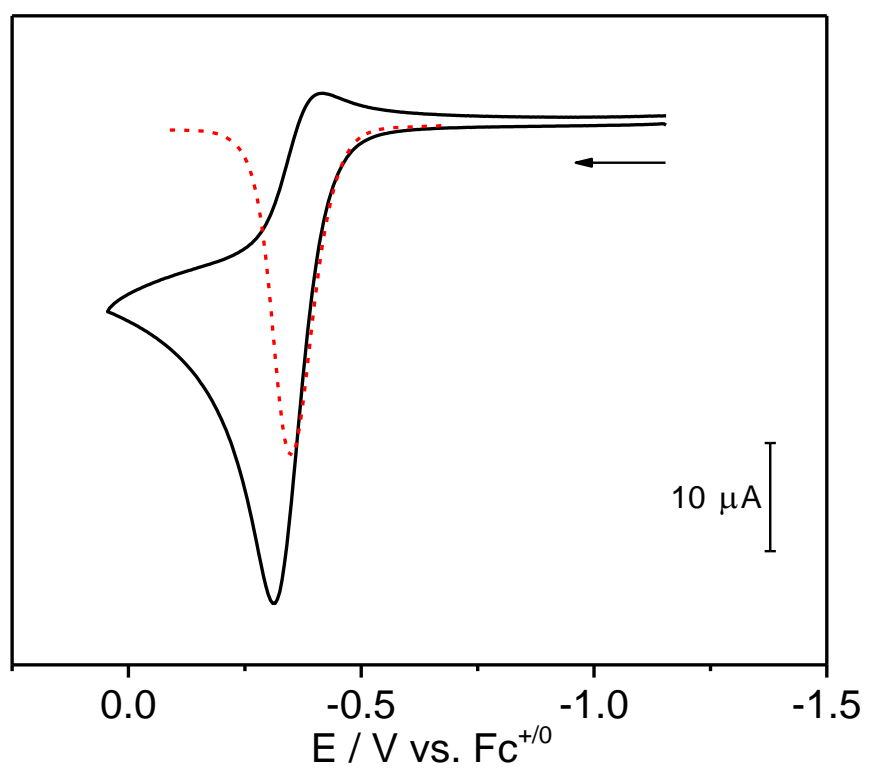

Figure S47. Cyclic voltammogram of ${ }^{\mathrm{Tr} M \mathrm{O}^{\circ} \mathrm{BIH}}$ in $\mathrm{MeCN}$ at room temperature (black solid line, scan rate 200 $\mathrm{mV} \mathrm{s}^{-1}, 0.1 \mathrm{M}\left[\mathrm{N}(\mathrm{n}-\mathrm{Bu})_{4}\right] \mathrm{PF}_{6}$, glassy carbon working electrode). Square-wave voltammogram measured under same condition is shown in red dashed line. 


\section{Stern Volmer Quenching Experiments}

Samples for Stern-Volmer quenching experiments were prepared individually in the drybox from stock solutions of ${ }^{\mathrm{TriMeO}} \mathrm{BIH}\left(\mathrm{E}_{\mathrm{ox}}=-0.33 \mathrm{~V}_{\mathrm{vs} \mathrm{FC}}{ }^{+/ 0}\right)$ in THF and corresponding $\mathrm{Zr}\left({ }^{\mathrm{Me} P D P}{ }^{\mathrm{R}}\right)_{2}\left(\mathrm{R}=\mathrm{C}_{6} \mathrm{~F}_{5}\right.$, $\mathrm{Ph}, \mathrm{H}, \mathrm{Me})$. The final concentration of $\mathrm{Zr}\left({ }^{\text {MePDP }}{ }^{\mathrm{R}}\right)_{2}$ for each measurement was $\sim 2 \cdot 10^{-5} \mathrm{M}$. Lifetime value were obtained via decay analysis software package, DAS v6.1, and Stern-Volmer plots were generated using the absolute concentration of the quencher for the corresponding sample.
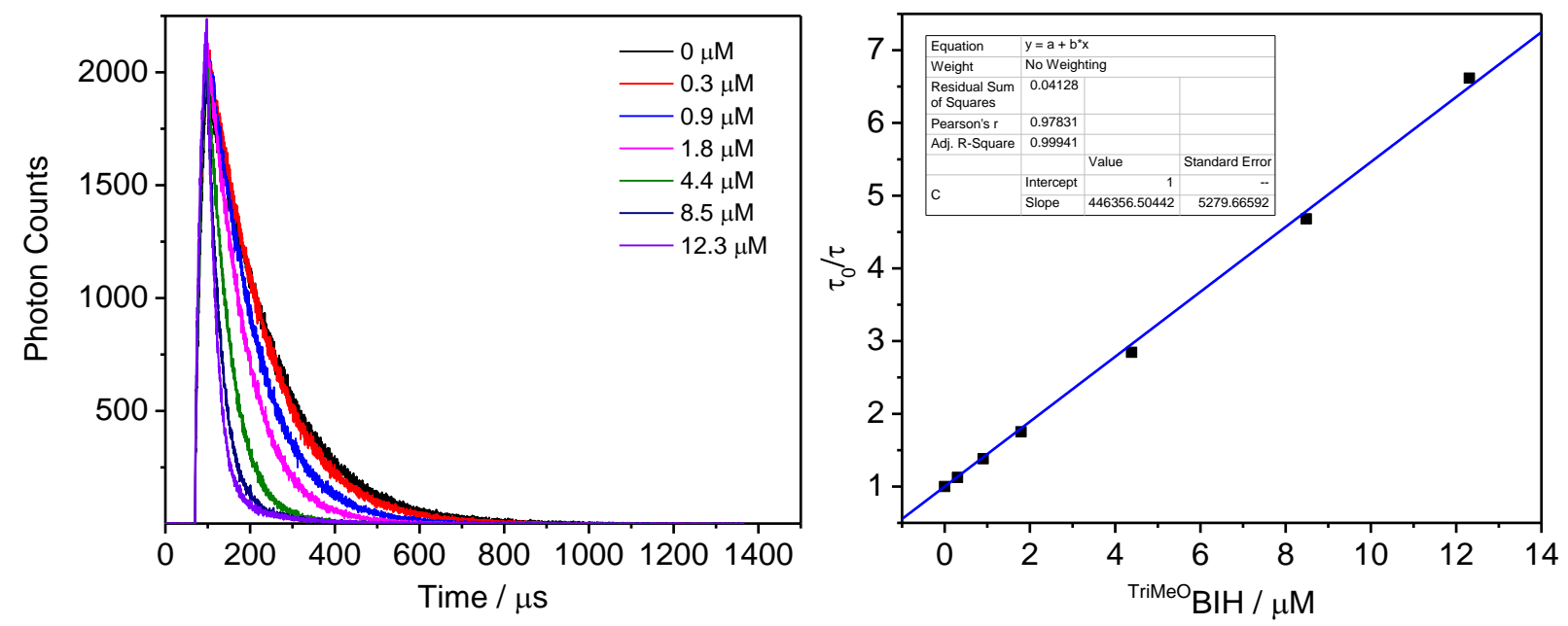

Figure S48. Quenching of $\mathrm{Zr}\left({ }^{\mathrm{Me} P D P}{ }^{\mathrm{C} 6 F 5}\right)_{2}$ by ${ }^{\text {TriMeO}}{ }^{\mathrm{BIH}}$ in THF. $\lambda_{\mathrm{ex}}=516 \mathrm{~nm}, \lambda_{\mathrm{em}}=620 \mathrm{~nm}$. Left: Time-resolved luminescence decays at different ${ }^{T r i M e O} \mathrm{BIH}$ concentration. Right: Stern-Volmer analyses.
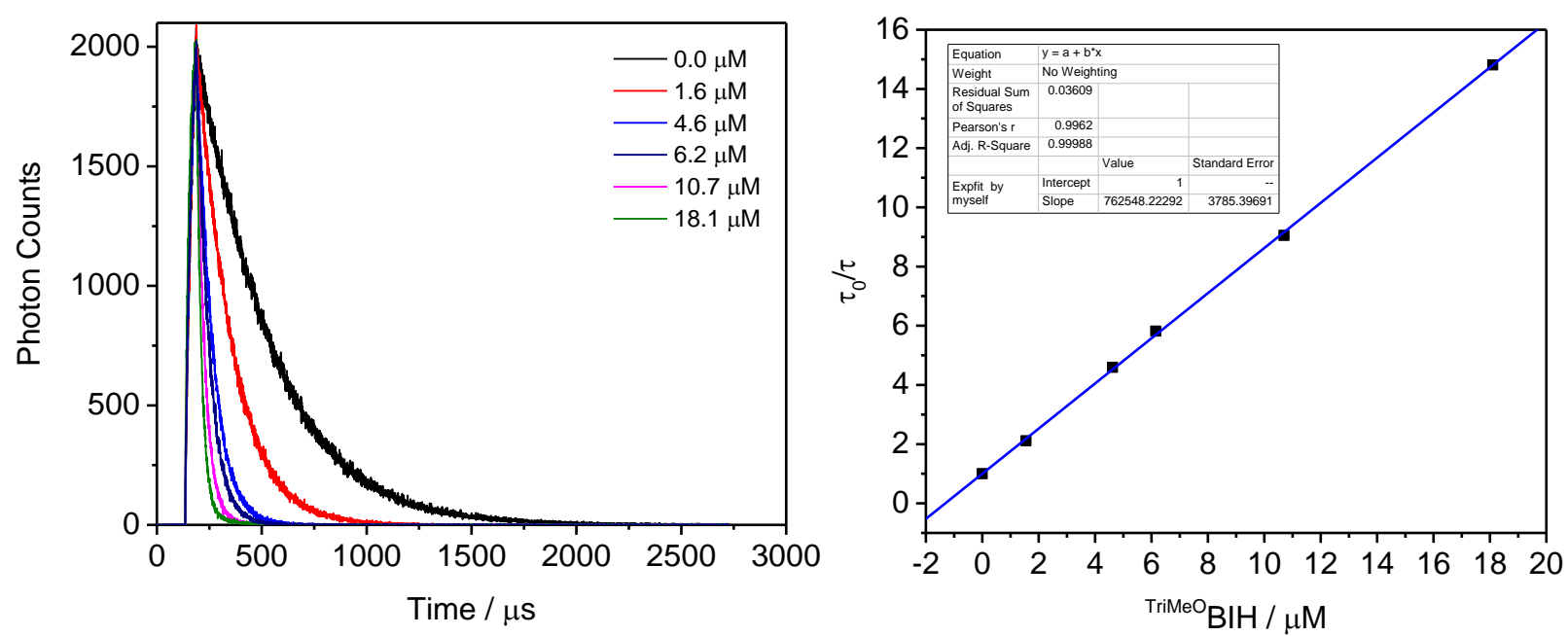

Figure S49. Quenching of $\mathrm{Zr}\left({ }^{\mathrm{Me} P D P}{ }^{\mathrm{Ph}}\right)_{2}$ by ${ }^{\mathrm{Tr} i M e O} \mathrm{BIH}$ in THF. $\lambda_{\mathrm{ex}}=516 \mathrm{~nm}, \lambda_{\mathrm{em}}=596 \mathrm{~nm}$. Left: Time-resolved luminescence decays at different ${ }^{\text {TriMeO}}{ }^{B I H}$ concentration. Right: Stern-Volmer analyses. 

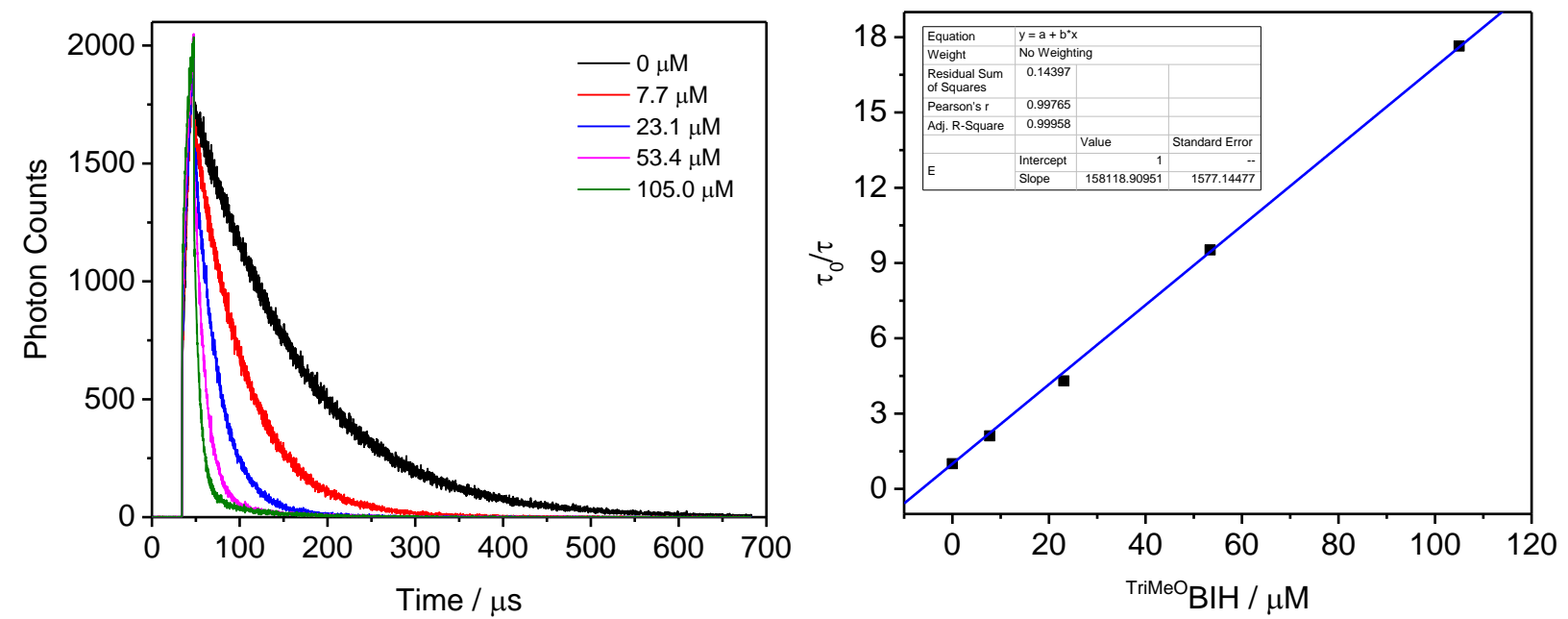

Figure S50. Quenching of $\mathrm{Zr}\left({ }^{\mathrm{Me} P D P}{ }^{\mathrm{H}}\right)_{2}$ by ${ }^{\mathrm{TriMeO}} \mathrm{BIH}$ in THF. $\lambda_{\mathrm{ex}}=516 \mathrm{~nm}, \lambda_{\mathrm{em}}=614 \mathrm{~nm}$. Left: Time-resolved luminescence decays at different ${ }^{\mathrm{TriMeO}} \mathrm{BIH}$ concentration. Right: Stern-Volmer analyses.
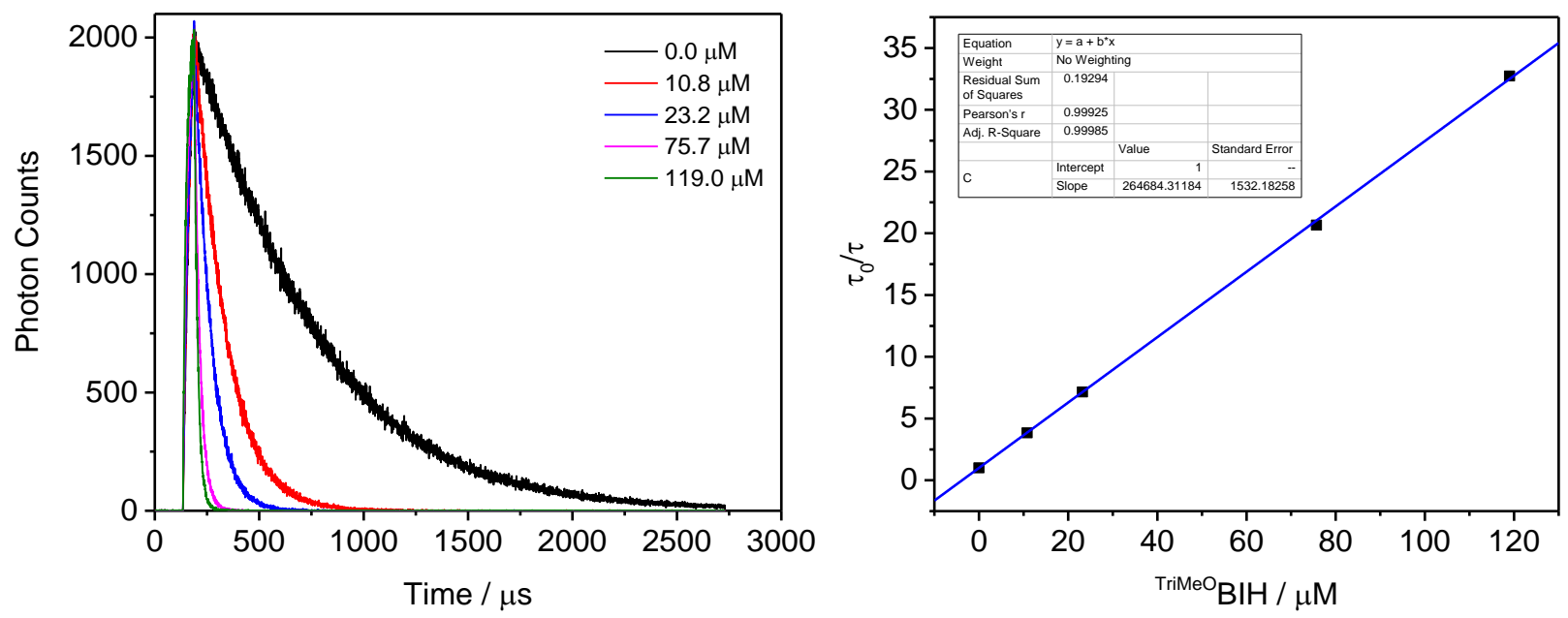

Figure S51. Quenching of $\mathrm{Zr}\left({ }^{\mathrm{Me}}{ }^{\mathrm{PDP}}{ }^{\mathrm{Me}}\right)_{2}$ by ${ }^{\mathrm{Tr} M{ }^{2} \mathrm{~B}} \mathrm{BIH}$ in THF. $\lambda_{\mathrm{ex}}=516 \mathrm{~nm}, \lambda_{\mathrm{em}}=584 \mathrm{~nm}$. Top: Time-resolved luminescence decays at different ${ }^{\text {TriMeO}}{ }^{B} \mathrm{BIH}$ concentration. Bottom: Stern-Volmer analyses. 


\section{General procedure for photocatalytic dehalogenation of aryl halides}

In the drybox, a J. Young NMR tube was charged with $\mathrm{Zr}\left({ }^{\text {MePDPMe }}{ }_{2}(0.10\right.$ equiv, from stock solution), TriMeoBIH (1.00 equiv), and aryl halide (1.00 equiv). Approximately $0.6 \mathrm{~mL}$ of $\mathrm{MeCN}-d_{3}$ was added. 1,3,5-trimethoxybenzene (from stock solution) was added as an internal standard. The mixture was placed in a jacketed glass beaker with water cooling and irradiated with green LED light $\left(\lambda_{\max }=520 \mathrm{~nm}\right)$. The reaction was monitored by NMR to judge the completion. The products were analyzed by NMR spectroscopy and the yields (conversion) are based on internal standard. The NMR spectroscopic data of dehalogenated products in MeCN- $d_{3}$ were established from commercially available pure materials.

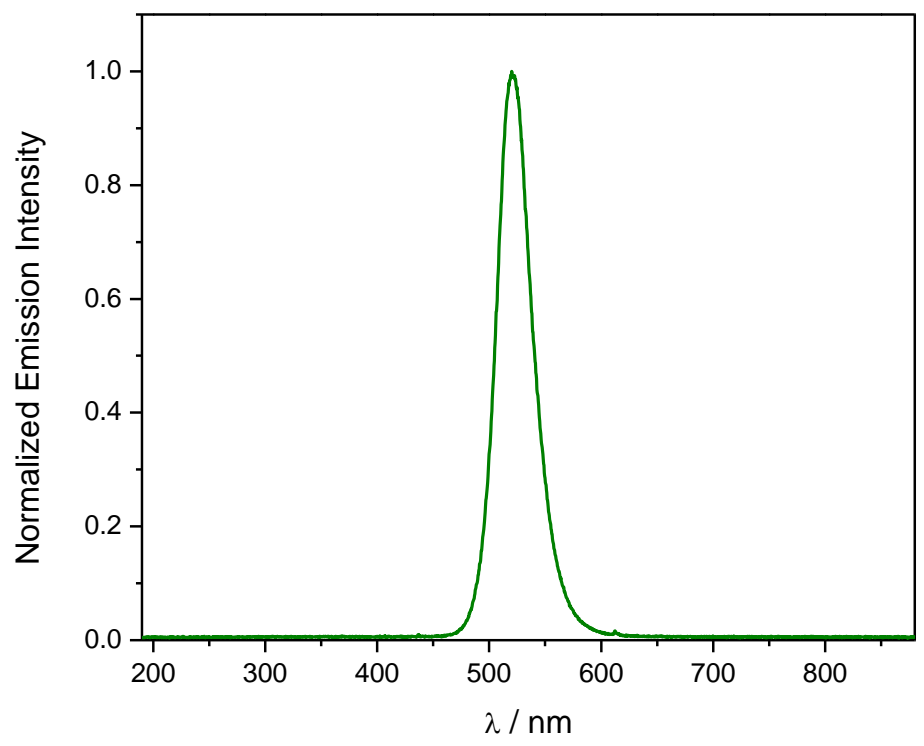

Figure S52. Emission profile of LED light strips used for photoredox reactions. 


\section{9. (TD-)DFT Calculations}

All DFT calculations were performed with the ORCA program package. ${ }^{6}$ Geometry optimizations of the complexes and single-point calculations on the optimized geometries were carried out at the B3LYP level of DFT. ${ }^{7-9}$ The all-electron Gaussian basis sets were those developed by the Ahlrichs group. ${ }^{10-12}$ Triple- $\zeta$ quality basis sets def2-TZVP with one set of polarization functions on the metal and on the atoms directly coordinated to the metal center were used. For the carbon and hydrogen atoms, slightly smaller polarized split-valence def2-SVP basis sets were used that were of double- $\zeta$ quality in the valence region and contained a polarizing set of $d$ functions on the non-hydrogen atoms. Auxiliary basis sets to expand the electron density in the resolution-ofthe-identity (RIJCOSX) ${ }^{13-15}$ approach were chosen to match the orbital basis. ${ }^{16-18}$ The conductorlike screening model (COSMO) was applied to model solvent effects in time-dependent DFT calculations. ${ }^{19}$ All molecular orbital and spin density plots were generated using the program Gabedit. $^{20}$

\subsection{Input File Examples}

Geometry Optimizations

! RKS B3LYP RIJCOSX SlowConv TightSCF def2-SVP def2-SVP/J Normalprint Opt

\%basis NewGTO 40 "def2-TZVP(-f)" end

NewGTO 7 "def2-TZVP(-f)" end

NewAuxGTO 40 "def2-TZVP/J" end

NewAuxGTO 7 "def2-TZVP/J" end

end

\%scf Maxlter 500

TolE 1E-7

TolErr 1E-6

end

*xyz 01

xyz coordinates from $X$-ray structure

$*$ 


\section{$\underline{\text { TD-DFT Calculations }}$}

! RKS B3LYP RIJCOSX SlowConv TightSCF def2-SVP def2-SVP/J COSMO(THF)

\%basis NewGTO 40 "def2-TZVP(-f)" end

NewGTO 7 "def2-TZVP(-f)" end

NewAuxGTO 40 "def2-TZVP/J" end

NewAuxGTO 7 "def2-TZVP/J" end

end

\%scf Maxiter 500

TolE 1E-7

TolErr 1E-6

end

\%tddft nroots 50

MaxDim 500

triplets false

end

${ }^{*} x y z \quad 01$

xyz coordinates from geometry optimization

\section{$*$}

10. References

(1) "APEX3 Is a Bruker AXS Crystallographic Software Package for Single Crystal Data Collection, Reduction and Preparation." APEX 3 is a Bruker AXS crystallographic software package for single crystal data collection, reduction and preparation.

(2) Sheldrick, G. M. "SHELXL-2014, Crystallographic Software Package." SHELXL-2014, Crystallographic software package, Bruker AXS, Inc., Madison, Wisconsin, USA.

(3) Würth, C.; Grabolle, M.; Pauli, J.; Spieles, M.; Resch-Genger, U. "Relative and Absolute Determination of Fluorescence Quantum Yields of Transparent Samples." Nature protocols 2013, 8, 1535-1550.

(4) Brouwer, A. M. "Standards for Photoluminescence Quantum Yield Measurements in Solution (IUPAC Technical Report)." Pure and Applied Chemistry 2011, 83, 2213-2228.

(5) Zhang, Y.; Lee, T. S.; Favale, J. M.; Petersen, J. L.; Scholes, G. D.; Castellano, F. N.; Milsmann, C. "Delayed Fluorescence from a Zirconium(IV) Photosensitizer with Ligand-to-Metal 
Charge-Transfer Excited States." Nature Chemistry 2020, 12, 345.

(6) Neese, F. "The ORCA Program System." Wiley Interdisciplinary Reviews: Computational Molecular Science 2012, 2, 73-78.

(7) Becke, A. D. "Density Functional Calculations of Molecular Bond Energies." The Journal of Chemical Physics 1986, 84, 4524-4529.

(8) Becke, A. D. "Density-Functional Thermochemistry. III. The Role of Exact Exchange." The Journal of Chemical Physics 1993, 98, 5648-5652.

(9) Lee, C.; Yang, W.; Parr, R. G. "Development of the Colle-Salvetti Correlation-Energy Formula into a Functional of the Electron Density." Physical Reviews B 1988, 37, 785-789.

(10) Schäfer, A.; Horn, H.; Ahlrichs, R. "Fully Optimized Contracted Gaussian-Basis Sets for Atoms Li to Kr." The Journal of Chemical Physics 1992, 97, 2571-2577.

(11) Schäfer, A.; Huber, C.; Ahlrichs, R. "Fully Optimized Contracted Gaussian Basis Sets of Triple Zeta Valence Quality for Atoms Li to Kr." The Journal of Chemical Physics 1994, 100, 58295835.

(12) Weigend, F.; Ahlrichs, R. "Balanced Basis Sets of Split Valence, Triple Zeta Valence and Quadruple Zeta Valence Quality for H to Rn: Design and Assessment of Accuracy." Physical Chemistry Chemical Physics 2005, 7, 3297-3305.

(13) Neese, F.; Wennmohs, F.; Hansen, A.; Becker, U. "Efficient, Approximate and Parallel Hartree-Fock and Hybrid DFT Calculations. A 'chain-of-Spheres' Algorithm for the HartreeFock Exchange." Chemical Physics 2009, 356, 98-109.

(14) Kossmann, S.; Neese, F. "Comparison of Two Efficient Approximate Hartee-Fock Approaches." Chemical Physics Letters 2009, 481, 240-243.

(15) Neese, F. "An Improvement of the Resolution of the Identity Approximation for the Formation of the Coulomb Matrix." Journal of Computational Chemistry 2003, 24, 17401747.

(16) Eichkorn, K.; Treutler, O.; Öhm, H.; Häser, M.; Ahlrichs, R. "Auxiliary Basis Sets to Approximate Coulomb Potentials." Chemical Physics Letters 1995, 240, 283-289.

(17) Eichkorn, K.; Treutler, O.; Öhm, H.; Häser, M.; Ahlrichs, R. “Erratum: Auxiliary Basis Sets to Approximate Coulomb Potentials (Chem . Phys . Letters 240 (1995) 283)." Chemical Physics Letters 1995, 242, 652-660.

(18) Eichkorn, K.; Weigend, F.; Treutler, O.; Ahlrichs, R. "Auxiliary Basis Sets for Main Row Atoms and Transition Metals and Their Use to Approximate Coulomb Potentials." Theoretical Chemistry Accounts 1997, 97, 119-124. 
(19) Klamt, A.; Schürmann, G. "COSMO: A New Approach to Dielectric Screening in Solvents with Explicit Expressions for the Screening Energy and Its Gradient." Journal of the Chemical Society, Perkin Transactions II 1993, 799-805.

(20) Allouche, A.-R. "Software News and Updates Gabedit-A Graphical User Interface for Computational Chemistry Softwares." Journal of Computational Chemistry 2011, 32, 174182. 